\title{
How to Ensure the Quality of Construction Works for Marine Platforms with Reference to Midia Gas Development Project - ANA Platform \& Doina Well \& Gas Treatment Plant -
}

\author{
Roxana Doina Schiau
}

Abstract - The Midia Gas Development Project is a new offshore gas project which has been developed and built in the last 30 year in the maritime territory of Romania. Once completed, it will have the ability to cover around $10 \%$ of gas needs of Romanian population.

Currently there is about $10 \mathrm{Bcm}$ of resources to be produced at a rate of about 1 Bcm per annum.

The infrastructure was thought to be used for the production of gas from the reservoirs of Ana and Doina, in the first place. But the long term vision of the project consists in converting the already existent infrastructure to develop green energy projects, such an offshore wind plant, solar panels fields or production of hydrogen, projects that may start time before decommissioning of the gas production platform.

Keywords -gas production platform, maritime territory, offshore gas project

\section{INTRODUCTION}

The reservoirs, called Doina and Ana were discovered in 1995 and 2007 during several drilling campaigns. Both Doina and Ana are biogenic gas reservoirs of Miocene to Dacian age, their positions is in the XV Midia Shallow Area, which is located at around $120 \mathrm{~km}$ offshore from Romanian coast and the water depth is about 70 meters.

The Midia Gas Development Project, in short MGD Project, has the following main components: five production wells -4 wells at Ana and 1 well at Doina, a subsea production system which will connect the Doina well, through a pipeline of $18 \mathrm{~km}$, to a production platform over Ana. All these systems are then connected to shore through a 121 $\mathrm{km}$ subsea pipeline and a $4.1 \mathrm{~km}$ underground pipeline to an onshore Gas Treatment Plant located to Vadu, Constanta. The gas processed at Vadu will be then delivered into the National Transmission System, now operated by Transgaz.

Black Sea Oil \& Gas had completed all offshore activities by the end of 2018, such as drilling activities, surveys, and pipeline route. For the onshore part of the project, by the end of 2018 all lands were already acquired, and other major activities related to the project were finalized (archaeological and route surveys, engineering studies, etc.). As mentioned before, BSOG has an obligation to deliver part of the gas produced to Transgaz for the next 15 years. BSOG has also made a long-term agreement with a subsidiary of ENGIE for gas selling. 
The main contractor for the EPCIC (Engineering, procurement, construction, installation and commissioning) contract has been assigned to GSP Offshore which will also drill the five wells by deploying the GSP Uranus jack-up rig.

"In February 2019, BSOG's partners and shareholders took the Final Investment Decision in the MGD Project. The project will cost roughly $\$ 400 \mathrm{~mm}$ and all the contracting activities for this project will have, in total, Romanian content of $70 \%$.

In 2019, BSOG completed the detailed engineering for the MGD Project, commenced the fabrication of the Ana Wellhead Platform at the shipyard in Agigea, commenced the civil constructions at the GTP site in Corbu and had purchased a number of long lead company items.

In 2020 important milestones were reached including the under-shore crossing (HDD) in Vadu area of the gas pipeline. The HDD operation involved the drilling and pulling of the gas pipeline between the onshore site, under the beach, and out into the sea for $1.5 \mathrm{kms}$. This was a first in Romania for an under shore crossing out into the Black Sea.

Moving forward to the sea, the offshore pipeline from the shore to Ana platform was run, some $120 \mathrm{~km}$ offshore. The laying of the pipeline from the shore to Ana platform location as well as the $18 \mathrm{~km}$ pipeline from Ana platform to the Doina well location started in October 2020 and was finalized in late January 2021.

Works at the Gas Treatment Plant were well underway with all concrete foundation having been installed and a steady progress reached. In parallel, the works at the onshore pipeline that will connect the shore pipe with the gas treatment plant in Vadu was started.

The outlook for Q1 and Q2 2021 includes completing the fabrication of the Ana production platform made of the jacket and the topside, the installation of the jacket and topside on Ana location in the Black Sea and drilling of the five production wells. The remainder of the onshore activities is expected to be completed by Q4 2021 with the first production of gas expected to occur in 4Q 2021.” [1]
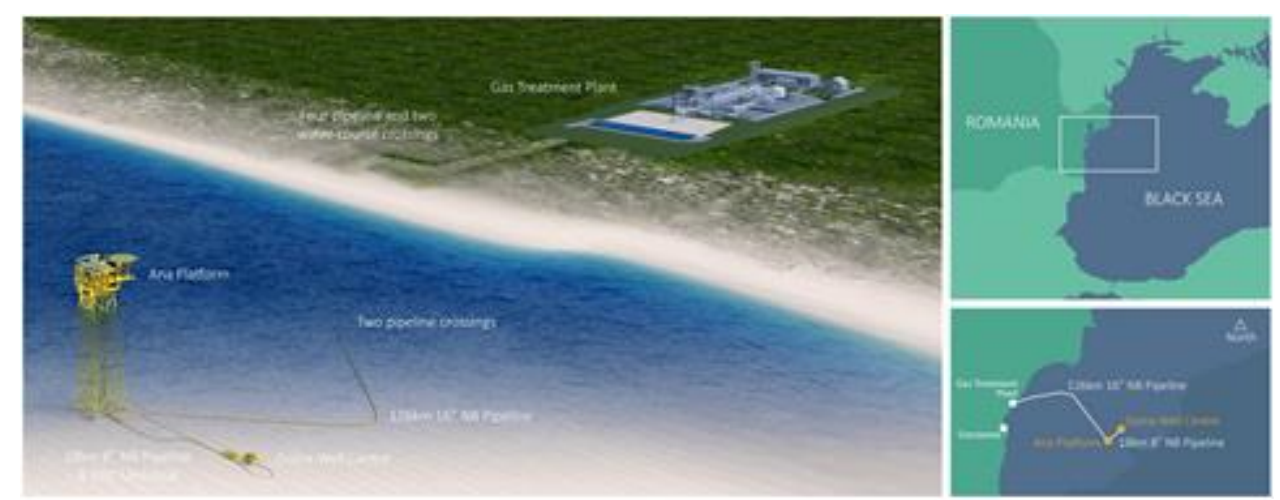

Fig. 1. MGD Project Scheme [2]

\section{PROJECT QUALITY PLAN - FACILITIES INSTALLATION}

The facilities required for the development can be summarised as follows:

- Doina: The field will be a single, vertical subsea well tied back, via an 8" x 18kilometre pipeline, to the Ana Platform - well controlled via an electro-hydraulic-chemical (EHC) umbilical providing electrical power, control, hydraulic power and MEG. A flanged tie in spool will be installed at the Doina location to accommodate any future near-field gas discovery. 


\section{sciendo}

176 Ovidius University Annals Series: Civil Engineering, Year 23, 2021

- Ana: Will be an unmanned Wellhead Platform with $4 \times$ wells, pipework fully rated to well closed-in tubing head pressure, cold vent, helideck, chemical storage and injection pumps for MEG, temporary refuge, lifeboat, facility to enable temporary installation of pig receivers/launchers, and minimal other facilities.

- Ana to shore pipeline: 16-inch x $121 \mathrm{~km}$ carbon steel pipeline with concrete coating for stability, continuously inhibited against hydrates with MEG.

- Beach crossing: 1,500 m horizontally directional drilled beach crossing.

- Pipeline from the beach crossing to the Gas Treatment Plant: trenched and buried 16-inch x $4 \mathrm{~km}$ carbon steel pipeline, continuously inhibited against hydrates with MEG.

- Onshore gas treatment plant: Pig receiver, slug catcher/separator, single stage turbine driven compressor (with scrubbers and air-cooled aftercooler), triethylene glycol (TEG) dehydration of gas, fiscal metering, MEG regeneration and storage, control room, power generation, utilities, cold vent, etc.

Gas produced from the Midia Gas Development will be exported to the onshore gas transmission network.

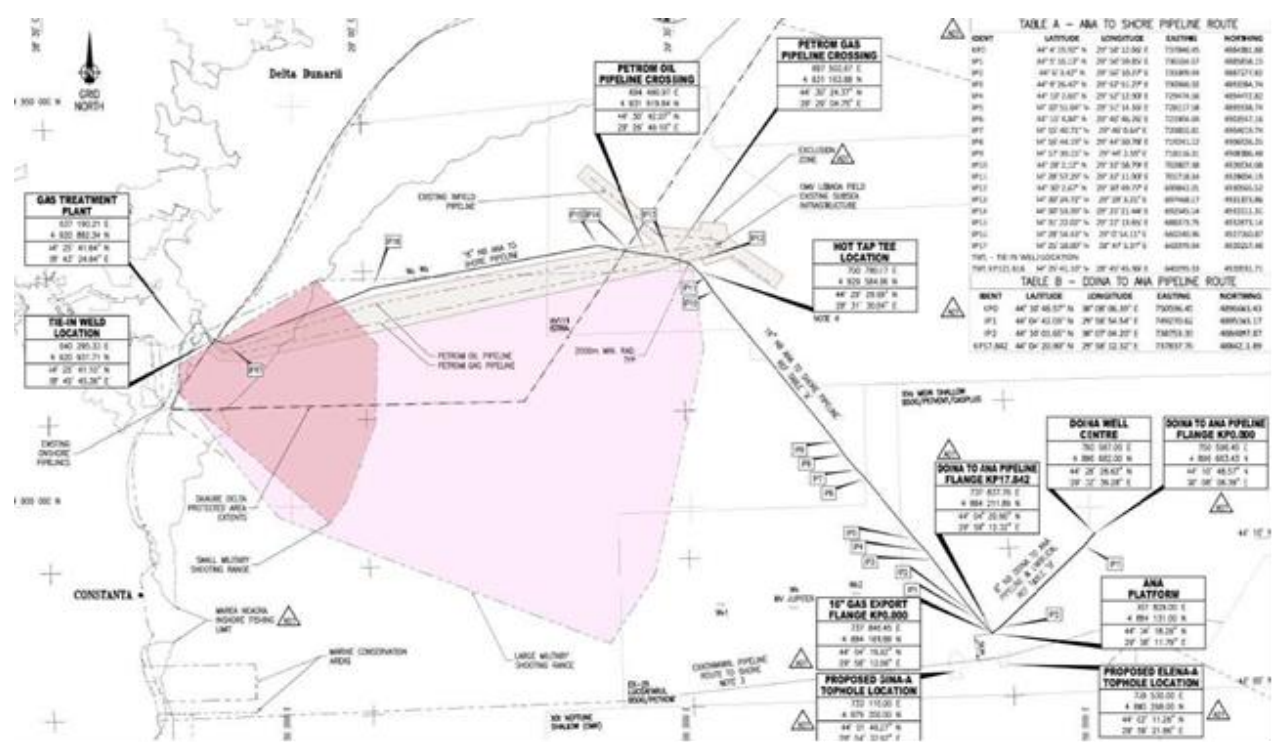

Fig. 2. Overall Field Layout for Midia Gas Development [2]

This Project Quality Plan (PQP) is a supporting document to the Project Management Plan and is one of the key management plans for the project and as such it will be reviewed for its adequacy at least once a year by the Project Manager and Department heads (as required).

This document establishes, describes and defines the following:

- ESTA's QMS including quality policy, objectives and Key Performance Indicators (KPIs).

- Quality requirements definition, implementation and compliance monitoring.

- QA/QC organisation, roles, responsibilities and authorization.

- Recording/reporting, investigating, addressing and closing out non-conformances (both product and system related).

- Actions necessary to monitor, evaluate and/or measure compliance and improve processes within the overall Project Management.

- Supportive actions to other functions. 
This PQP applies to all activities undertaken by ESTA necessary to ensure compliance with the Contract and all applicable laws, codes and standards for ESTA Onshore Pipeline and Gas Treatment Plant Project.

- Mechanical;

- Pipelin;

- Electrical \& Instrumentation;

- Civils.

\section{QUALITY MANAGEMENT SYSTEM (QMS)}

ESTA will implement the QMS based on the requirements stipulated in the ISO 9001:2015 which will be defined in this document other ESTA Plans and associated procedures and will be guarded by the following approach to the Continual Improvement of the QMS.

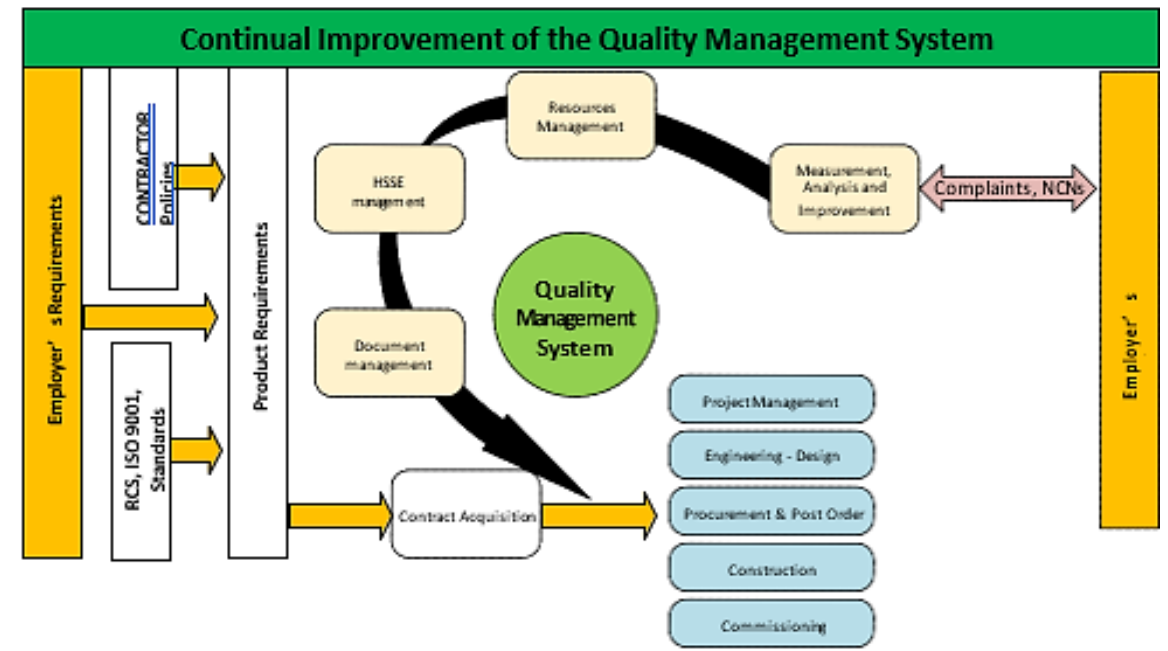

Fig. 3. Continual Improvement of the Quality Management System

The QMS will be documented through various documents and will establish both aspects of Quality, Quality Assurance and Quality Control. Project staff will be trained in the applicable principles and processes however all staff will be made aware of the basic QMS requirements through Quality Inductions which will be tailored and documented.

Project staff will be also made aware of the Process approach in relation to all Project activities, both internal (within ESTA and in regards to ESTA's Supplier's activities) as well as the external.

It is ESTA's intention to implement the "Plan-Do-Check-Act" in all of its activities and processes as explained in Section 7.10 of this document. ESTA has documented its QMS in accordance with the following:

Quality system documentation also defines criteria and methods needed to ensure that the operation and control of quality system processes are effective. This includes defining the purpose and scope for the process, assignment of responsibilities and allocation of resources for the process, definition of methods for monitoring and/or measuring the effectiveness of the process, identifying sub processes, and providing instructions on how to carry out the process (where applicable). 


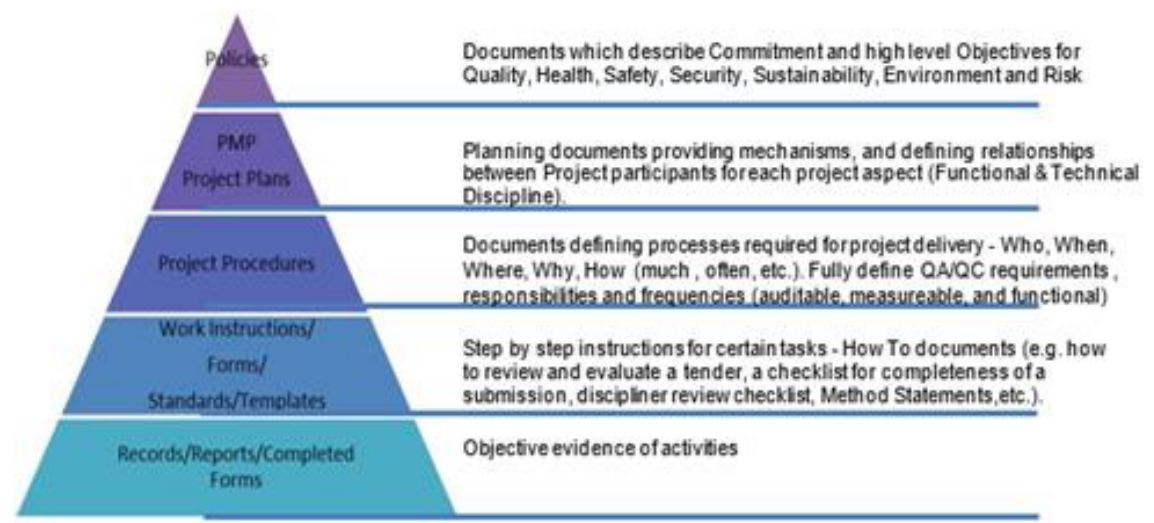

Fig. 4. Quality Management System Documented Scheme

Following is the main process that are interrelated and dependant on each other Quality.

Table 1 - Quality Management Process

\begin{tabular}{|c|l|}
\hline \multicolumn{2}{|c|}{ QUALITY MANAGEMENT } \\
\hline Purpose & $\begin{array}{l}\text { To implement and maintain a Quality Management System which is compliant with } \\
\text { ISO 9001 and RCS. To establish QC processes which will evaluate compliance of the } \\
\text { works with RCS. To certify completed works in accordance with applicable }\end{array}$ \\
\hline Owners & QA/QC Manager, QA Manager, QC Managers \\
\hline & $\begin{array}{l}\text { - Quality Planning - this document } \\
\text { - Quality Assurance - processes and procedures, training }\end{array}$ \\
& $\begin{array}{l}\text { - Quality Control - inspection and testing of materials and works } \\
\text { - Quality Auditing (both internal and external) }\end{array}$ \\
& - Self-Certification \\
\hline
\end{tabular}

\section{QUALITY OBJECTIVES AND KPIS}

In order to measure its performance and to ensure that Continual Improvement is part of the QMS, ESTA will be establishing, monitoring and reporting on the following KPIs wich will be mothly delivered by Contractor as a format to ESTA and Esta will be filling this form accordingly Table 2. From time to time and as required ESTA might introduce additional and periodical KPIs in order to provide further inputs into the Continual Improvement effort.

Table 2 - KPIs Table to Monitories

\begin{tabular}{|c|l|l|l|l|}
\hline No. & \multicolumn{1}{|c|}{ KPI } & Curent month & Year to Date & Comment \\
\hline 1 & Number of Neconformities & & & \\
\hline 2 & Number of Quality Audits & & & \\
\hline 3 & Number of NDT rejection & & & \\
\hline 4 & Percentage reduction in defect rates & & & \\
\hline 5 & Number of pressure test failed & & & \\
\hline 6 & Number of Quality training sessions & & & \\
\hline 7 & Customer satisfaction score & & & \\
\hline 8 & Audit findings closure performance & & & \\
\hline 9 & Passed tests rate & & & \\
\hline 10 & Welders performance rate & & & \\
\hline
\end{tabular}


There will also be a Monthly Quality Meeting between ESTA, D and QR and will include an agreed agenda.

Figure 5 describes the principle of establishing and monitoring the KPIs by all participants.

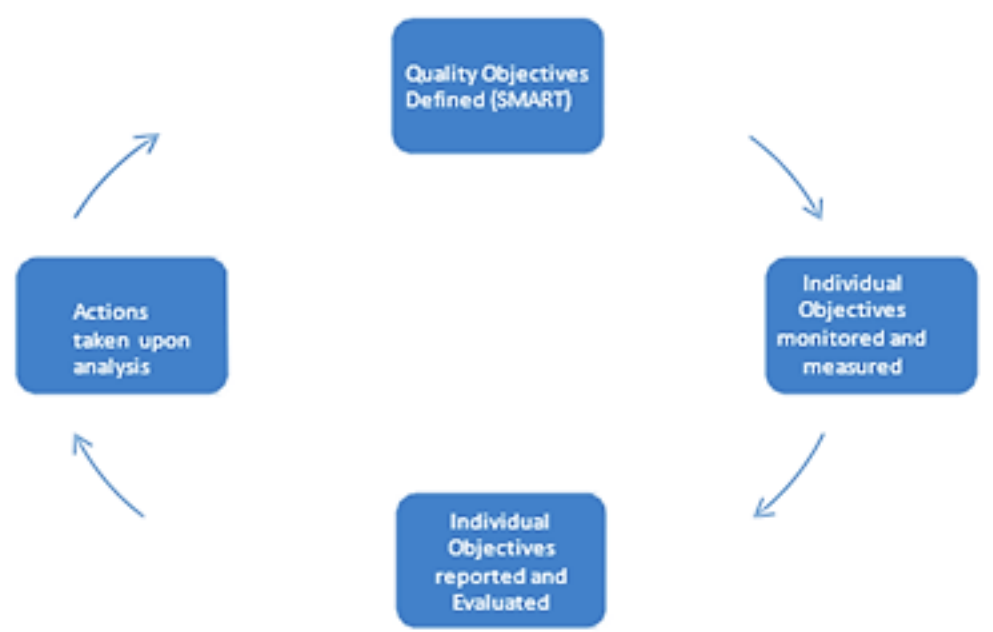

Fig. 5. KPIs Principles Described

\section{PLAN, DO, CHECK, ACT - CONTINUAL IMPROVEMENT}

The following Quality Improvement principle, as in ISO 9001:2015, shall be applied across all ESTA's activities, by all ESTA and its Subcontractors/Suppliers, in order to ensure continual improvement which shall be demonstrable by all project participants.

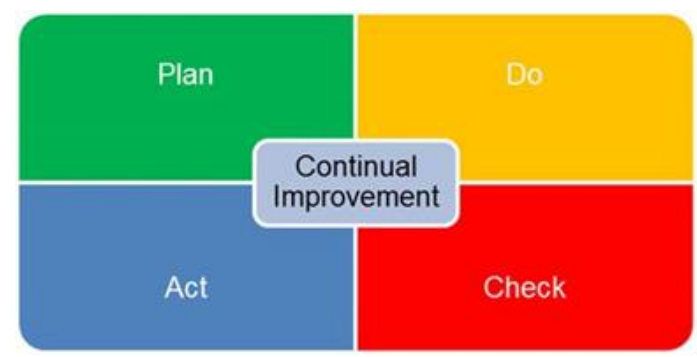

Fig. 6. Continual Improvement Plan

\section{EPC PRCESS MODEL}

The planning for the execution of EPC activities is established at the beginning and monitored by the Project Control Manager and controlled by the Site Manager. The planning programme and details regarding realisation of planning programme are included in the monthly reports issued to the Company. The implementation, supervision and verification of these processes, as well as the provision of the resources and documentation required, shall be carried out under control of the Project Director assisted by the Projects, Quality, Design and Construction Departments. 
The following EPC Process model (Figure 7) is applied to the Quality Management System for the successful completion of the project ensuring continuous improvement.

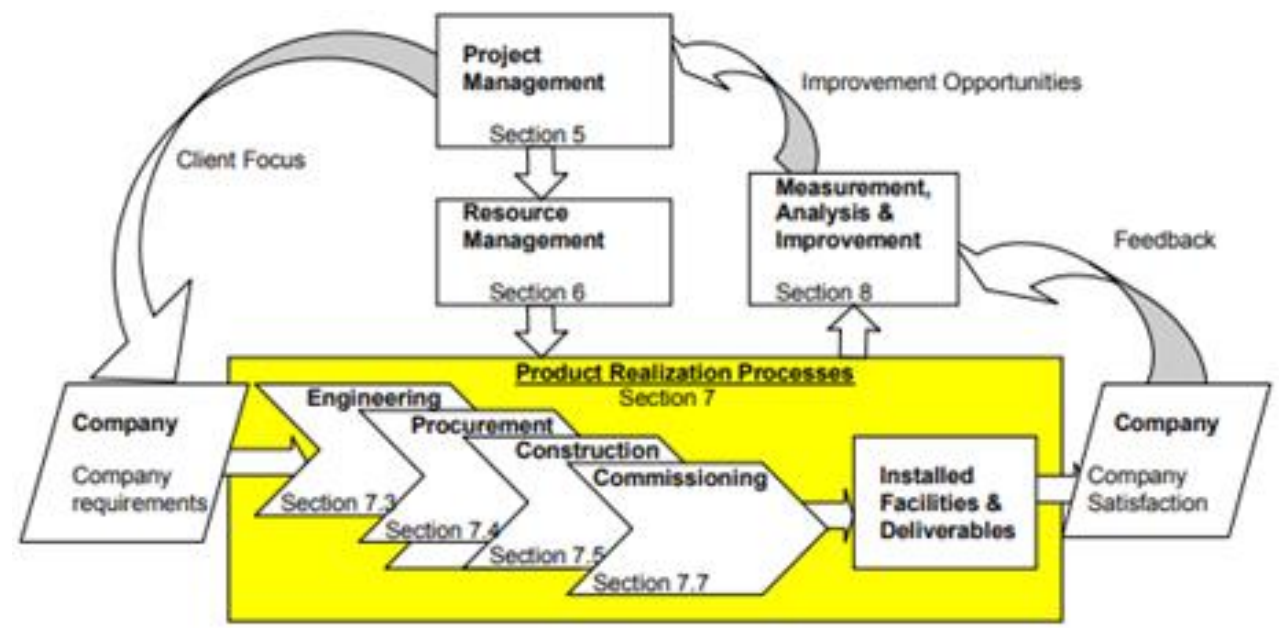

Fig. 7. EPC Process Scheme

The Contractor shall implement his ISO 9001:2000 certified Quality System in this project. The Quality Management System (QMS) aims to achieve Company satisfaction by meeting the contractual requirements.

\section{PROJECT IMPLEMENTATION}

The processes required for performing, monitoring and measuring, the EPC activities, their sequence and interaction are determined for this project in order to achieve error / defect free deliverables and facilities. The Cause and Effect Diagram for the project execution is shown in Figure 8.

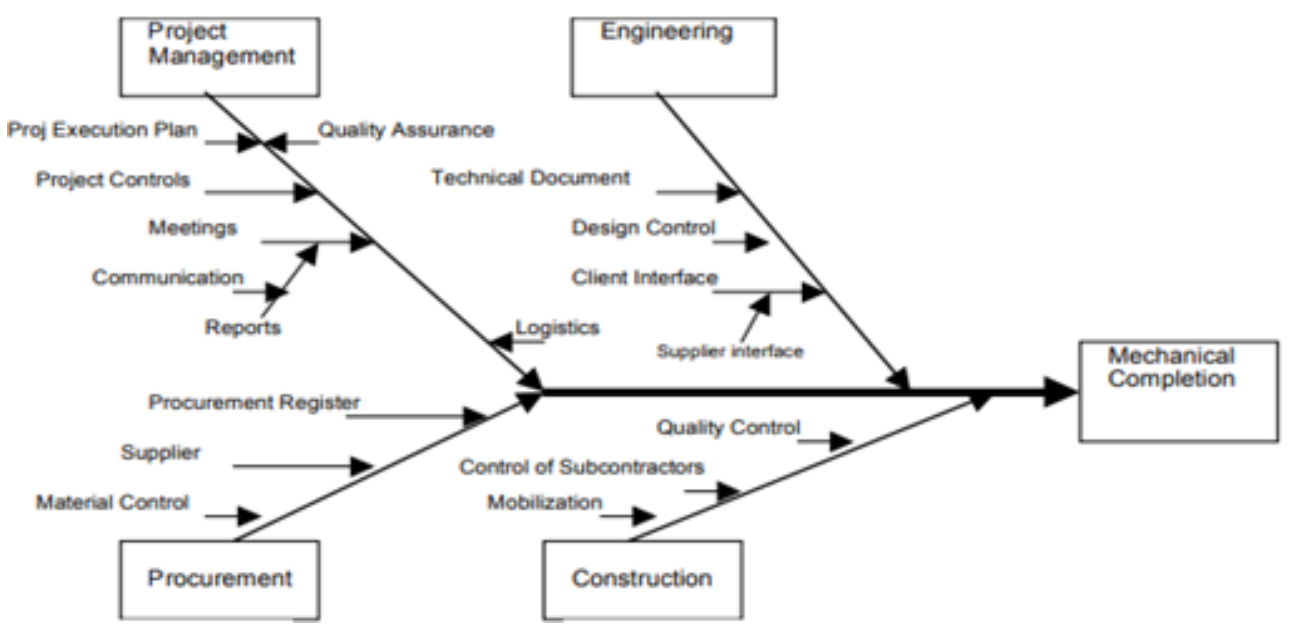

Fig. 8. Project Implementation Scheme 


\section{Planning For Project Implementation}

\section{Engineering / Procurement Phase}
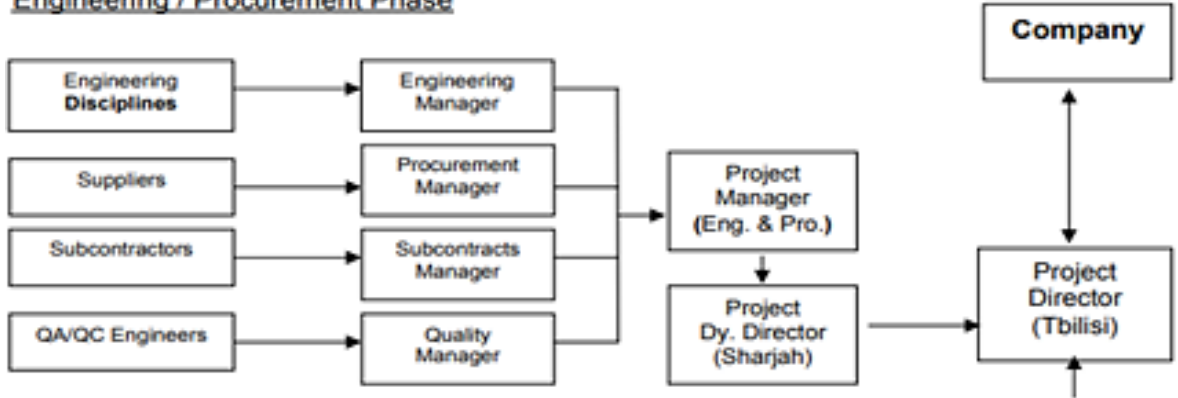

Construction / Commissioning Phase

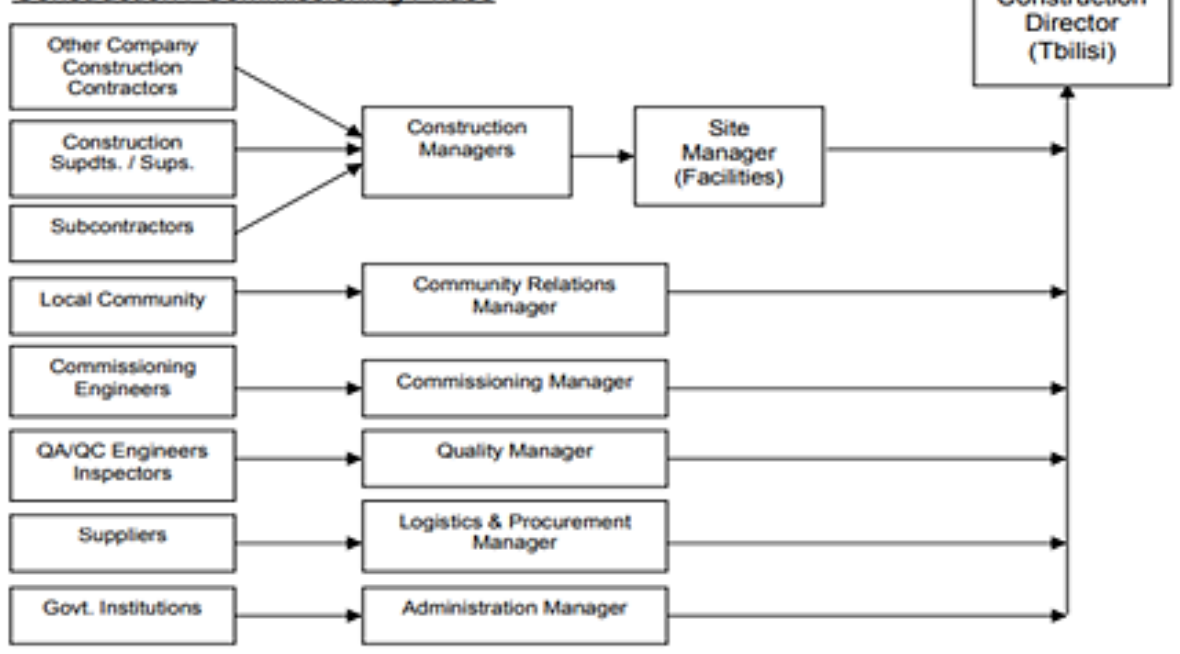

Fig. 9. Interface Management

\section{Planning for Quality}

The Quality Manager with his supporting staff performs quality planning for satisfying the quality requirements. The layers of quality planning documents are given below:

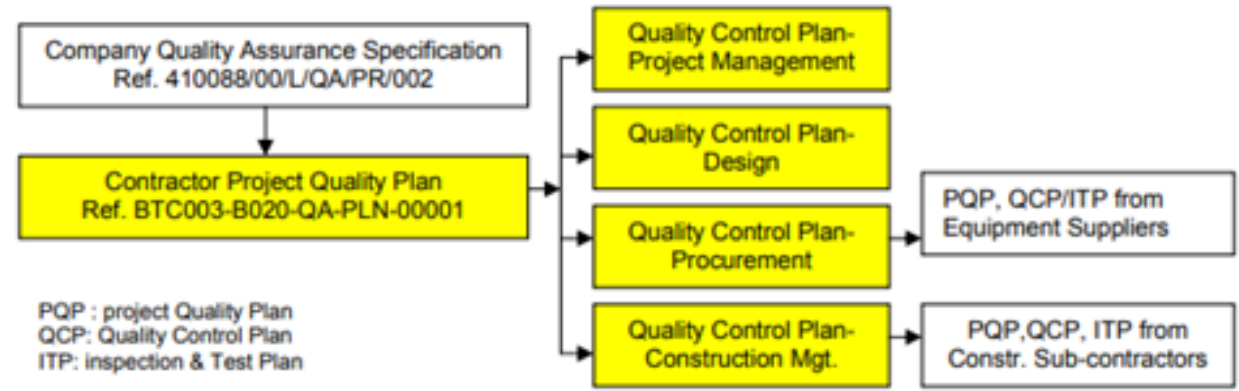

Fig. 10. Quality Planning Scheme 


\section{CONCLUSIONS}

"The MGD Project is permanently involved in promoting an organizational culture and improving the Quality Management System by observing the below quality principles:

1. Build a mutually profitable relationship with all our interested parties, ensuring their long-term success, through the understanding of their needs and the needs of their customers as well.

2. Achieve our commitments for quality, cost, and schedule. Processes will be developed and controlled to prevent errors before they occur.

3. Continuous improvement will be achieved by having an effective corrective and preventive action; program that will address and eliminate causes of nonconforming services and products.

4. Develop staff competencies, creativity, empowerment, and accountability through appropriate development programs and show strong management involvement and commitment." [3]

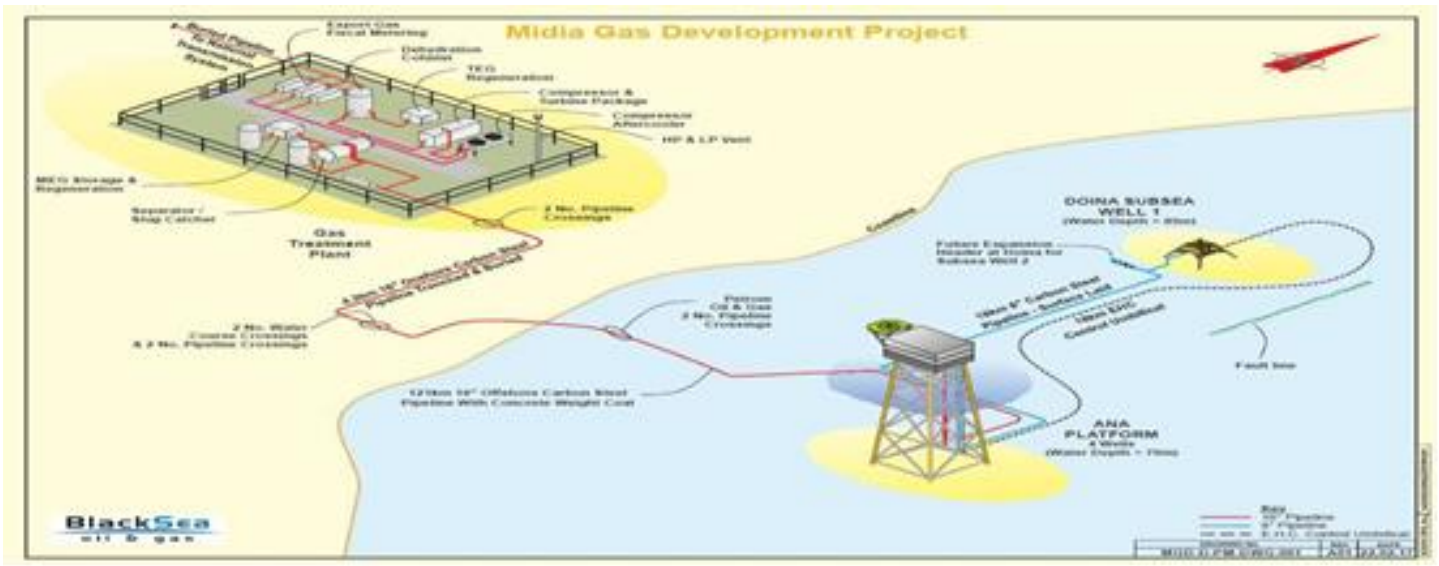

Fig. 11. Selected Concept for Midia Gas Development [2]

\section{DEFINITIONS AND ABBREVIATIONS}

For the purpose of delivering the project and establishing all supporting processes ESTA has adopted: Gas Development Project Acronyms and Definition of Terms. In addition to the definitions provided in the above-mentioned document ESTA will use the following (Table 3).

Table 3 - Abreviations used in the document

\begin{tabular}{|l|l|}
\hline Client & Black Sea Oil \& Gas S.A. \\
\hline CONTRACTOR & GSP OFFSHORE S.R.L. \\
\hline SUB-CONTRACTOR & ESTA CONSRUCTION GROUP S.R.L. \\
\hline Subcontractor/Supplier & $\begin{array}{l}\text { Any party (Vendor, Contractor, Consultant) engaged by the } \\
\text { CONTRACTOR to provide products and/or services for the }\end{array}$ \\
\hline Correction & $\begin{array}{l}\text { An action to eliminate a detected non-conformity - e.g., } \\
\text { rework, repair, re- grade material, scrap, grant concession to } \\
\text { use "As Is" - reactive action to allow for a process to continue }\end{array}$ \\
\hline
\end{tabular}




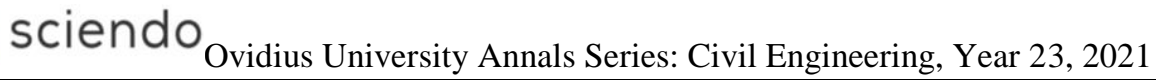

\begin{tabular}{|l|l|}
\hline Corrective Action & $\begin{array}{l}\text { An action to eliminate the cause of a detected non- } \\
\text { conformity or other undesirable situation - there can be } \\
\text { multiple causes for non-conformity - reactive action. }\end{array}$ \\
\hline Aconex & Electronic Data Management System - (EDMS) \\
\hline BSOG & Black Sea Oil \& Gas S.A. \\
\hline PV & Project Verifier \\
\hline ESTA & ESTA CONSTRUCTION GROUP SRL \\
\hline D & $\begin{array}{l}\text { Fesigner } \\
\text { product as per the Codification Manual and Aconex }\end{array}$ \\
\hline FC Drawing & GSP OFFSHORE SRL \\
\hline GSP & Inspection Request \\
\hline IRE & Inspection and Test Plan \\
\hline ITP & Key Performance Indicator (Quality Objective) \\
\hline KPI & Monoethylene glycol \\
\hline MEG & Mechanical, Electrical \& Plumbing \\
\hline MEP & Method Statements \\
\hline MES & $\begin{array}{l}\text { Non-conformance Notification: An instrument used by the D to } \\
\text { address an issue which in the EA's opinion constitutes an NCR }\end{array}$ \\
\hline NCN & Non-Conformance Report \\
\hline NCR & Notification for Inspection \\
\hline NOI & Project Manager - Contractor \\
\hline PMC & Project Quality Plan (Quality Management Plan) - this document \\
\hline PQP & $\begin{array}{l}\text { An action to eliminate the cause of a potential non- } \\
\text { conformity or other undesirable potential situation - proactive }\end{array}$ \\
\hline Preventive Action & Esta Onshore Pipeline and Gas Treatment Plant \\
\hline Project & Quality Assurance / Quality Control \\
\hline QA/QC & $\begin{array}{l}\text { Quality Control Manager (Head of QC Section, responsible for } \\
\text { an Area and multiple sites) }\end{array}$ \\
\hline QC Manager & $\begin{array}{l}\text { Quality Management System as defined in the ISO } \\
9000: 2005 \text { with the Requirements specified in the ISO } \\
9001: 2015 \text { and any subsequent revisions during the project } \\
\text { lifecycle. Also defined in the RCS 2015 with the reference to the }\end{array}$ \\
\hline QMS & Quality representative, Contractor \\
\hline QR & Romania Construction Specifications \\
\hline RCS & $\begin{array}{l}\text { An expression in the content of a document conveying criteria to } \\
\text { be fulfilled if compliance with the document is to be claimed and } \\
\text { from which no deviation is permitted (e.g., contract clauses, }\end{array}$ \\
\hline Requirement & $\begin{array}{l}\text { Request for Information (a tool utilized for matter } \\
\text { clarification between various Project participants) }\end{array}$ \\
\hline Senior Quality Assurance Manager \\
Triethylene glycol \\
\hline
\end{tabular}




\section{APPENDIX}

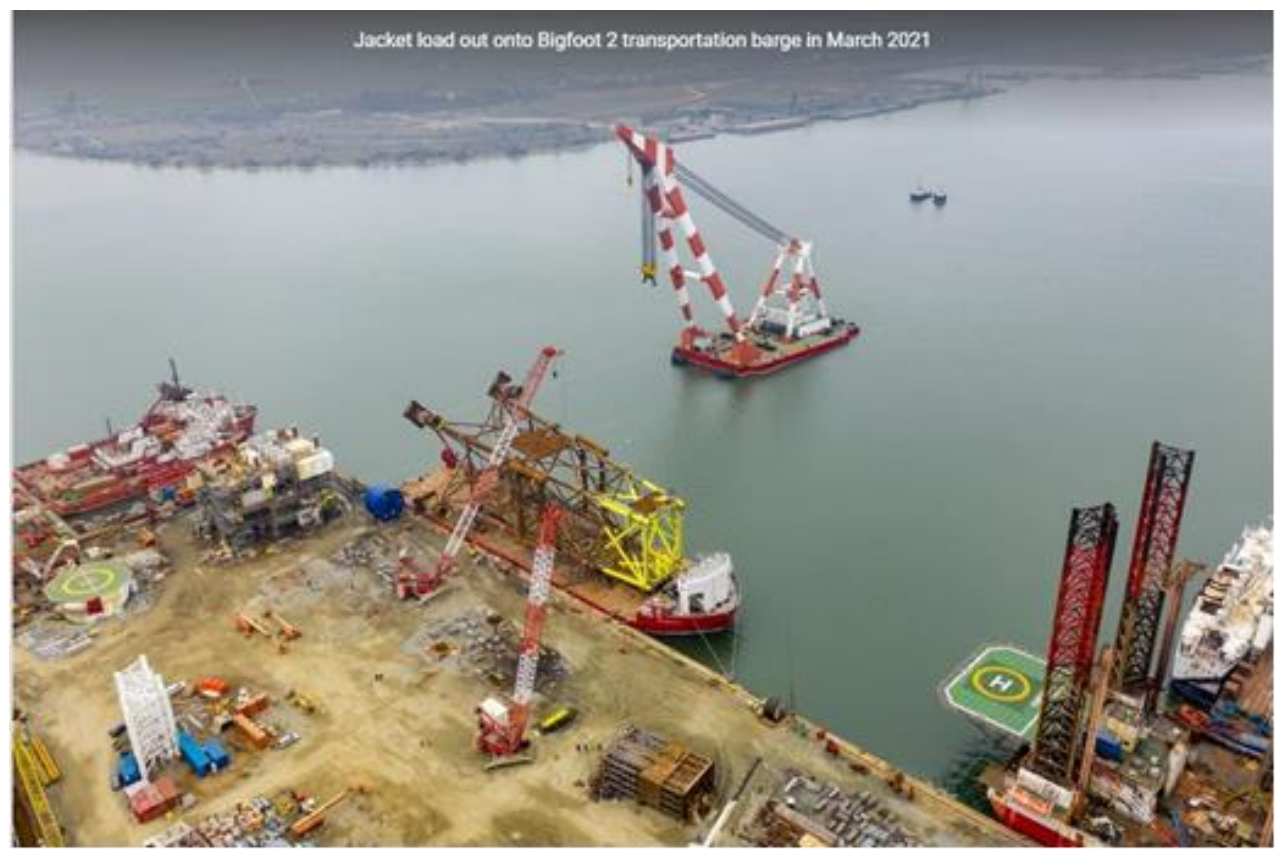

Fig. 12.1. Jacket load out onto Bigfoot 2 transportation barge [2]

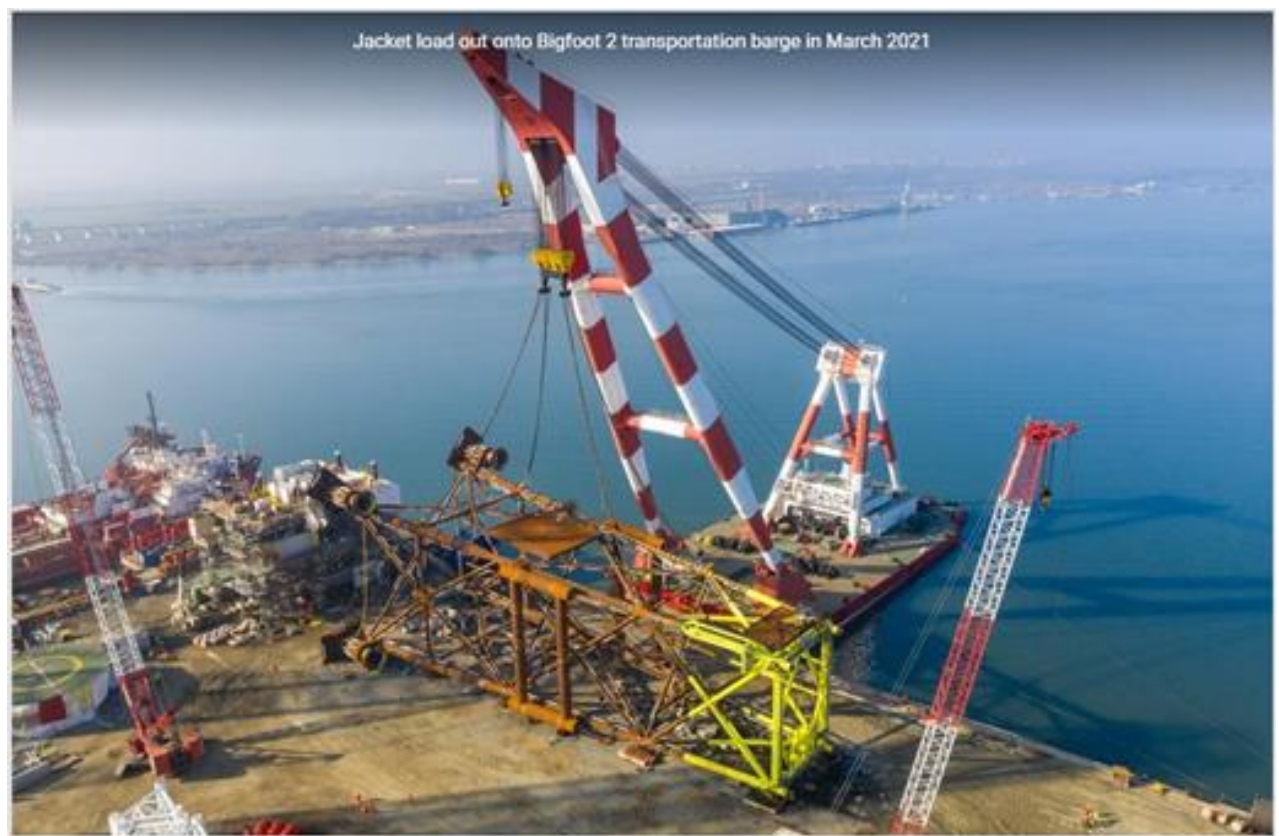

Fig. 12.2. Jacket load out onto Bigfoot 2 transportation barge [2] 


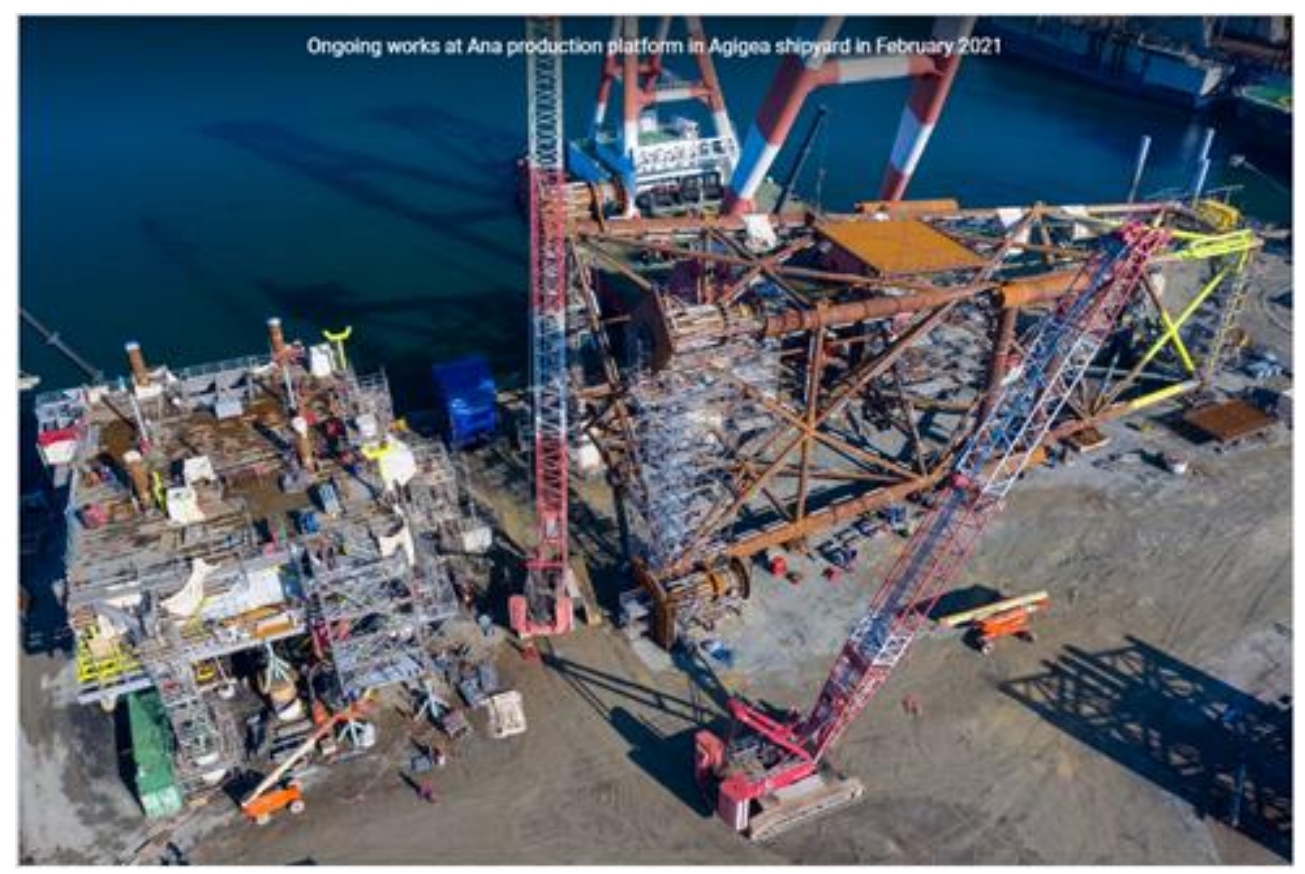

Fig. 13.1. Ongoing Works at Ana Platform in Agigea Shipyard [2]

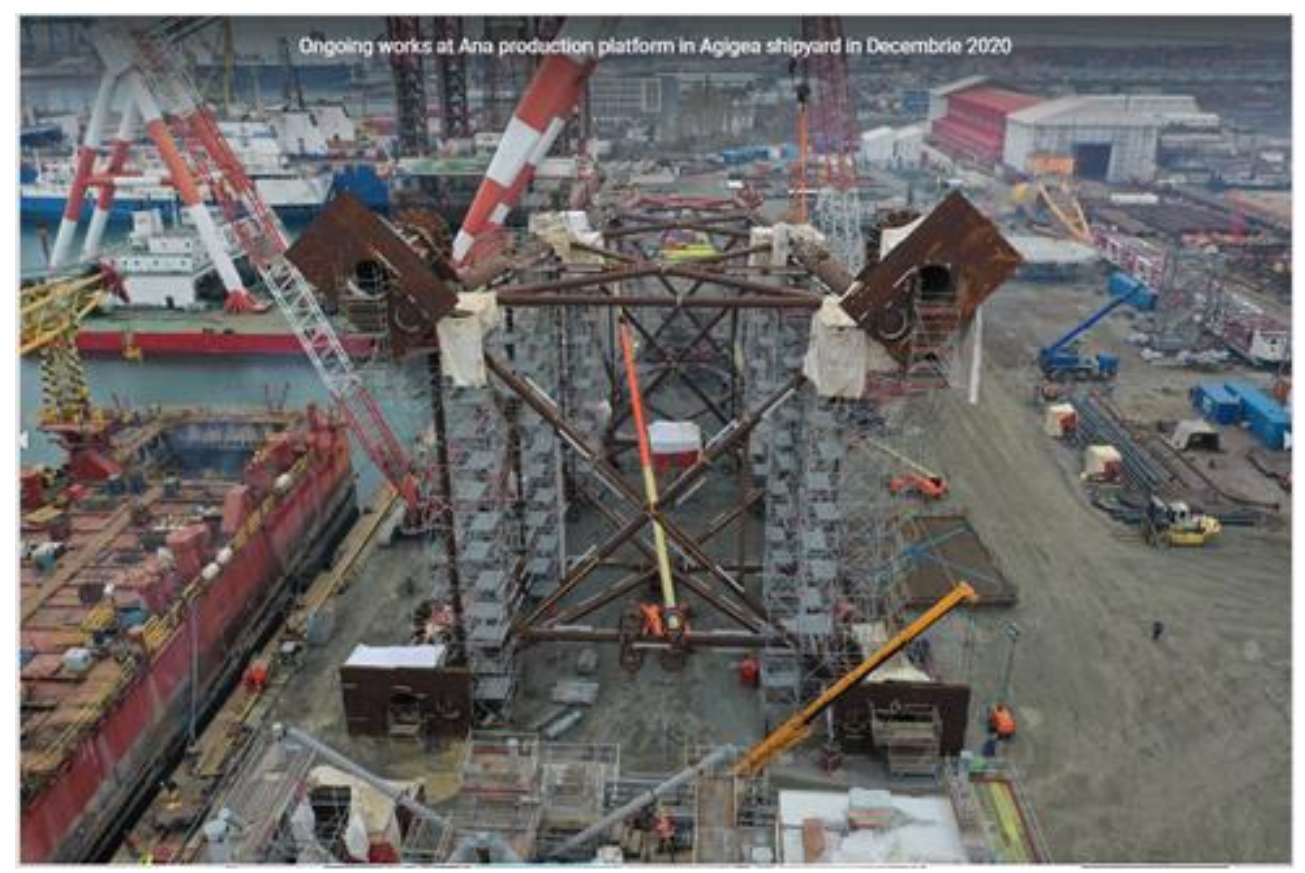

Fig. 13.2. Ongoing Works at Ana Platform in Agigea Shipyard [2] 


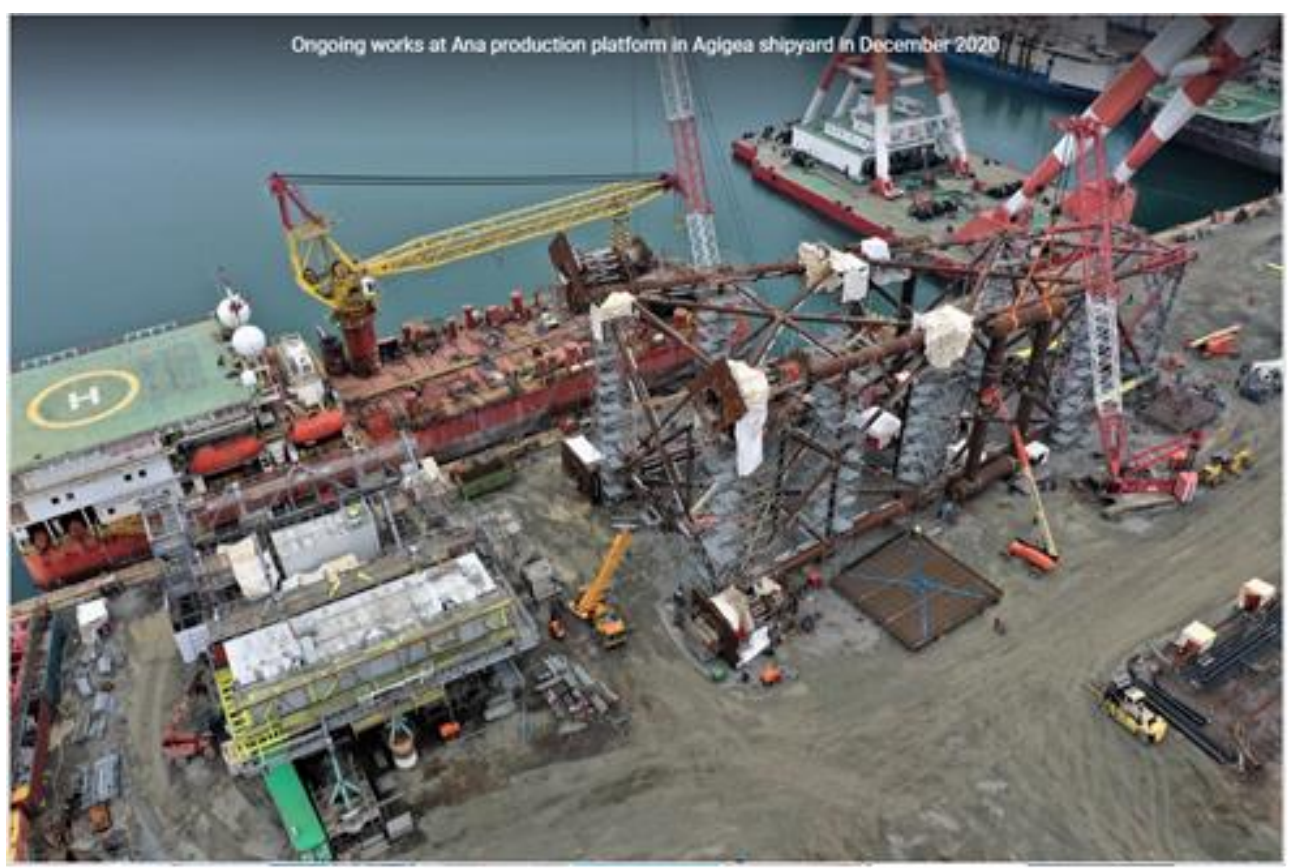

Fig. 13.3. Ongoing Works at Ana Platform in Agigea Shipyard [2]

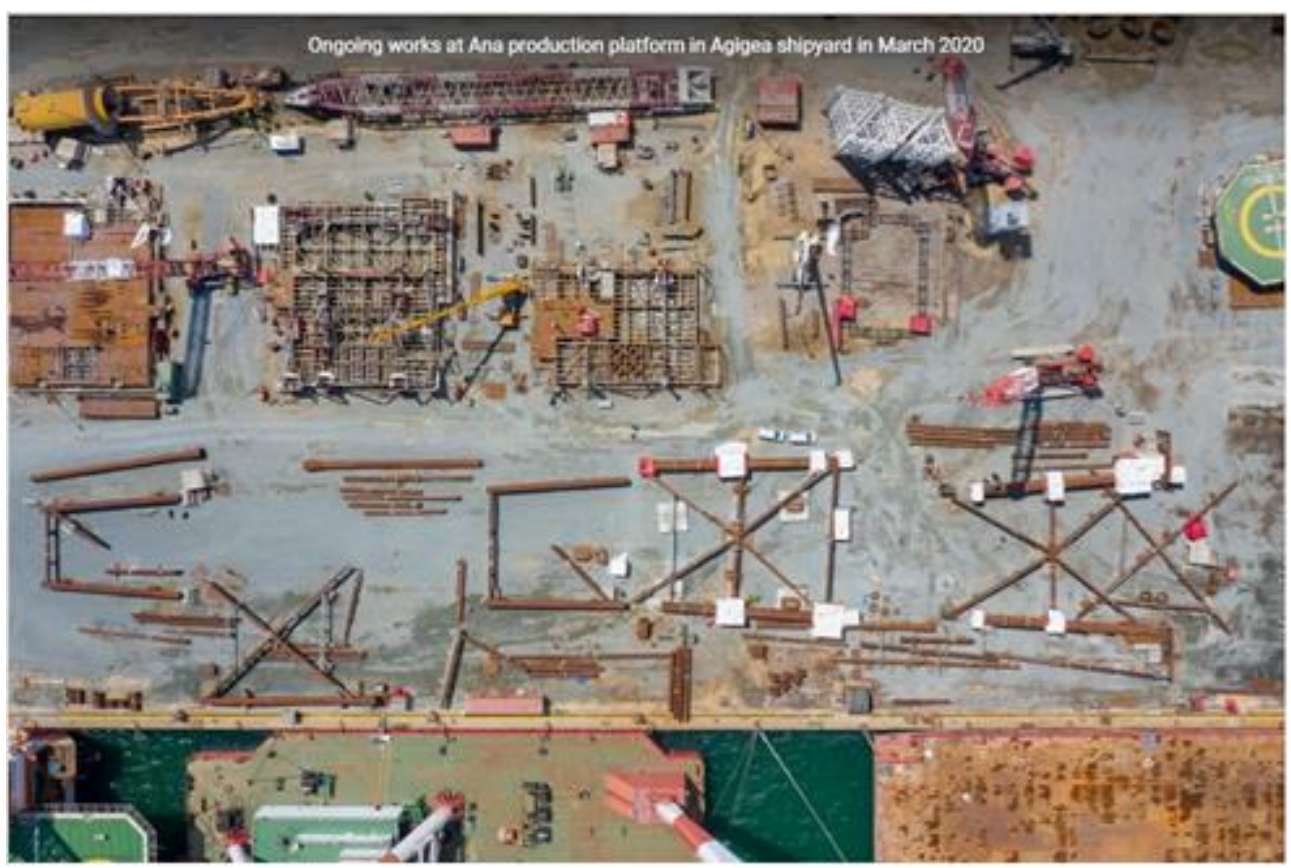

Fig. 13.4. Ongoing Works at Ana Platform in Agigea Shipyard [2] 


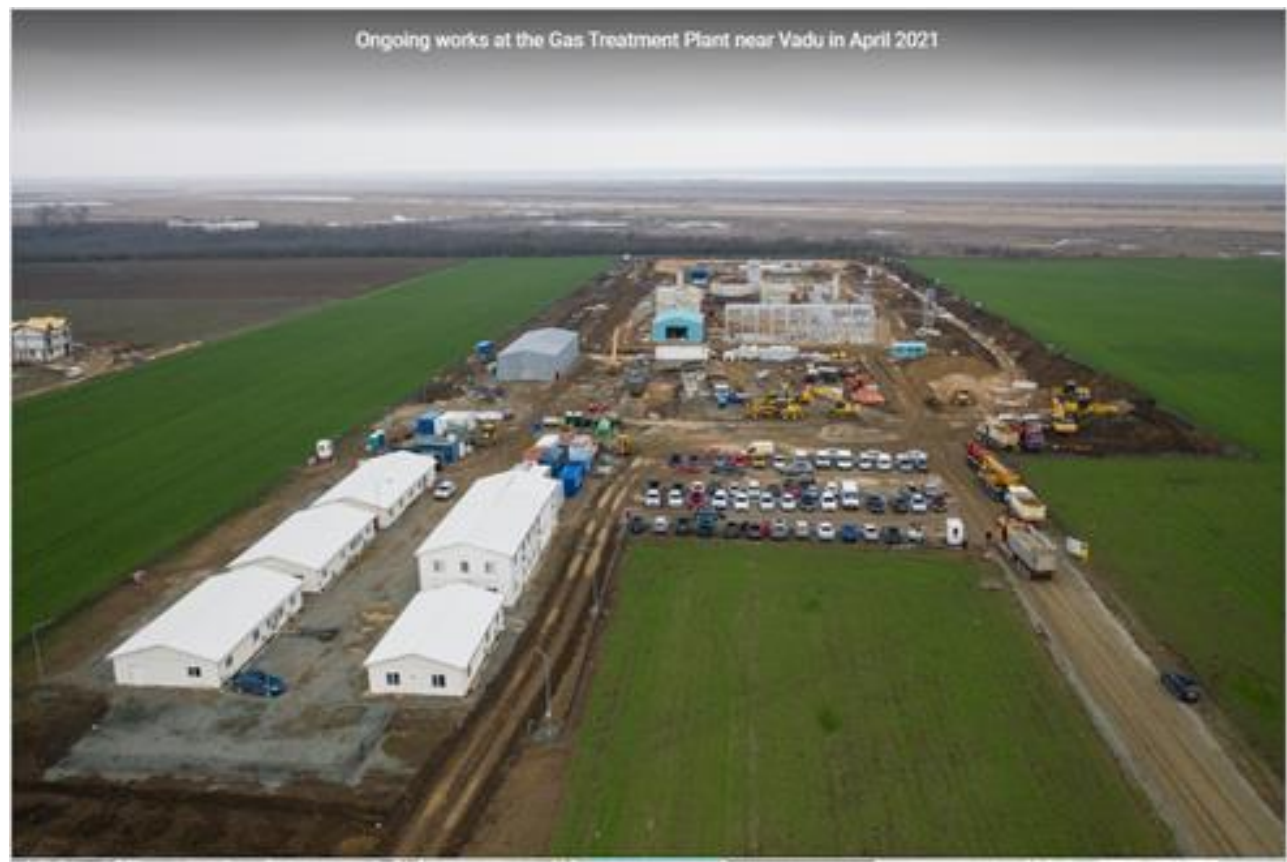

Fig. 14.1. Ongoing Works at Gas Treatment Plant in Vadu Site [2]

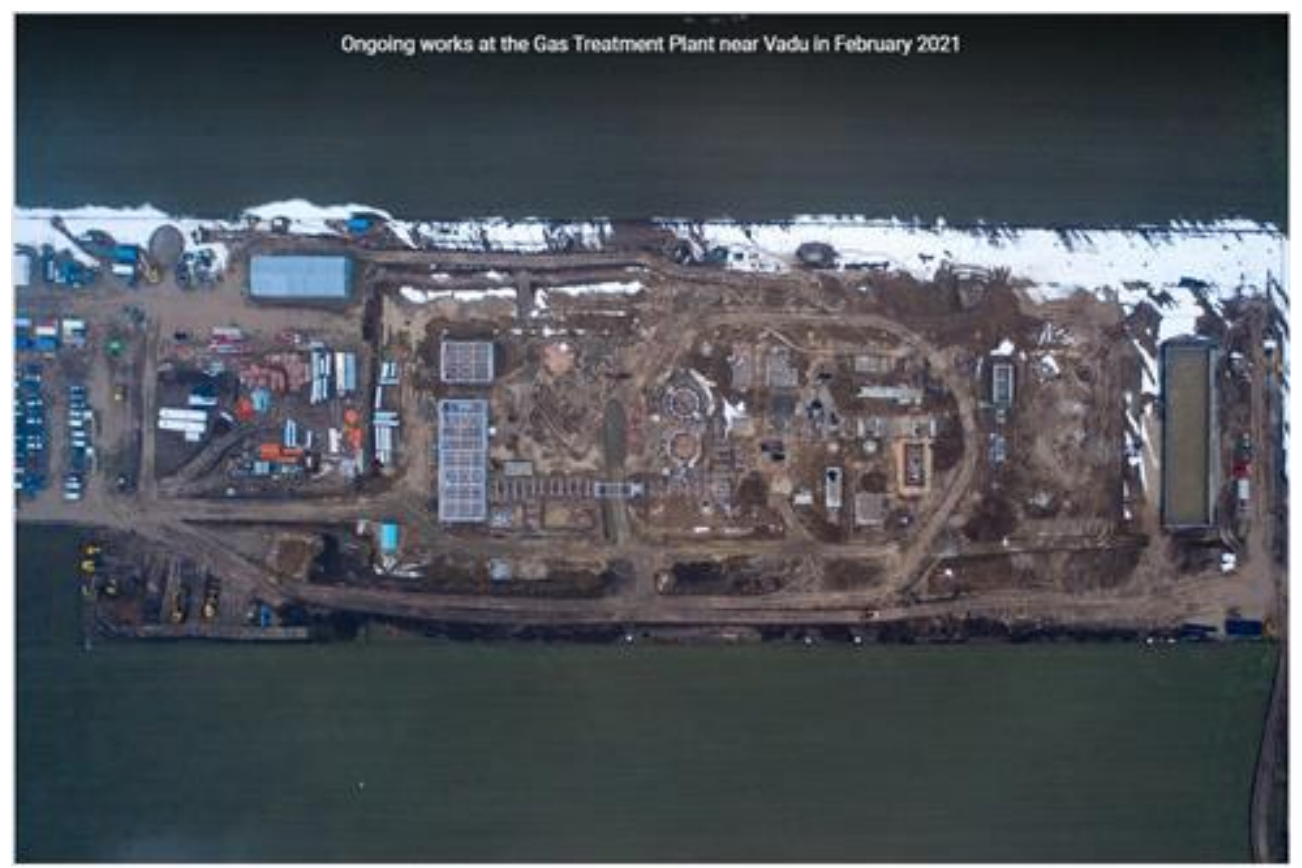

Fig. 14.2. Ongoing Works at Gas Treatment Plant in Vadu Site [2] 


\section{Sciendo $_{188}$ Ovidius University Annals Series: Civil Engineering, Year 23, 2021}

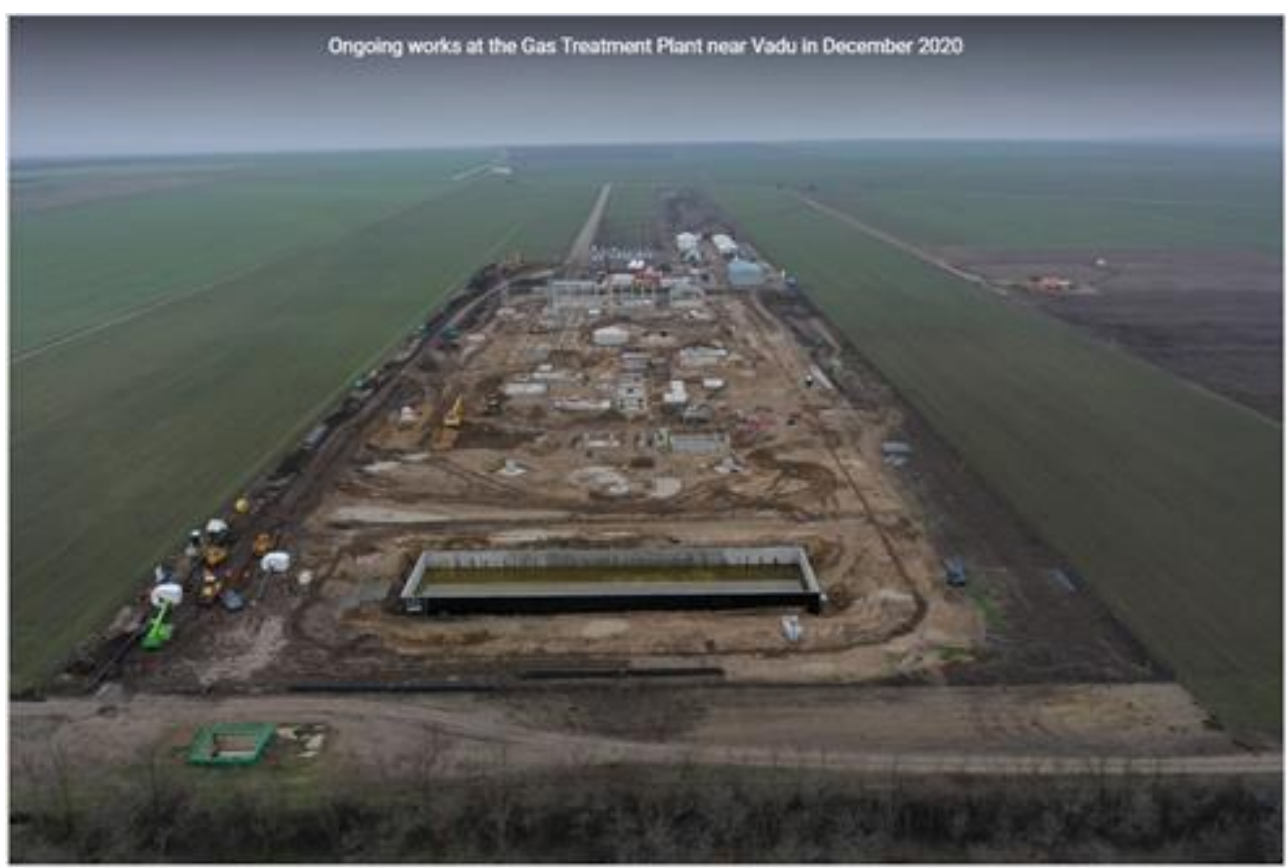

Fig. 14.3. Ongoing Works at Gas Treatment Plant in Vadu Site [2]

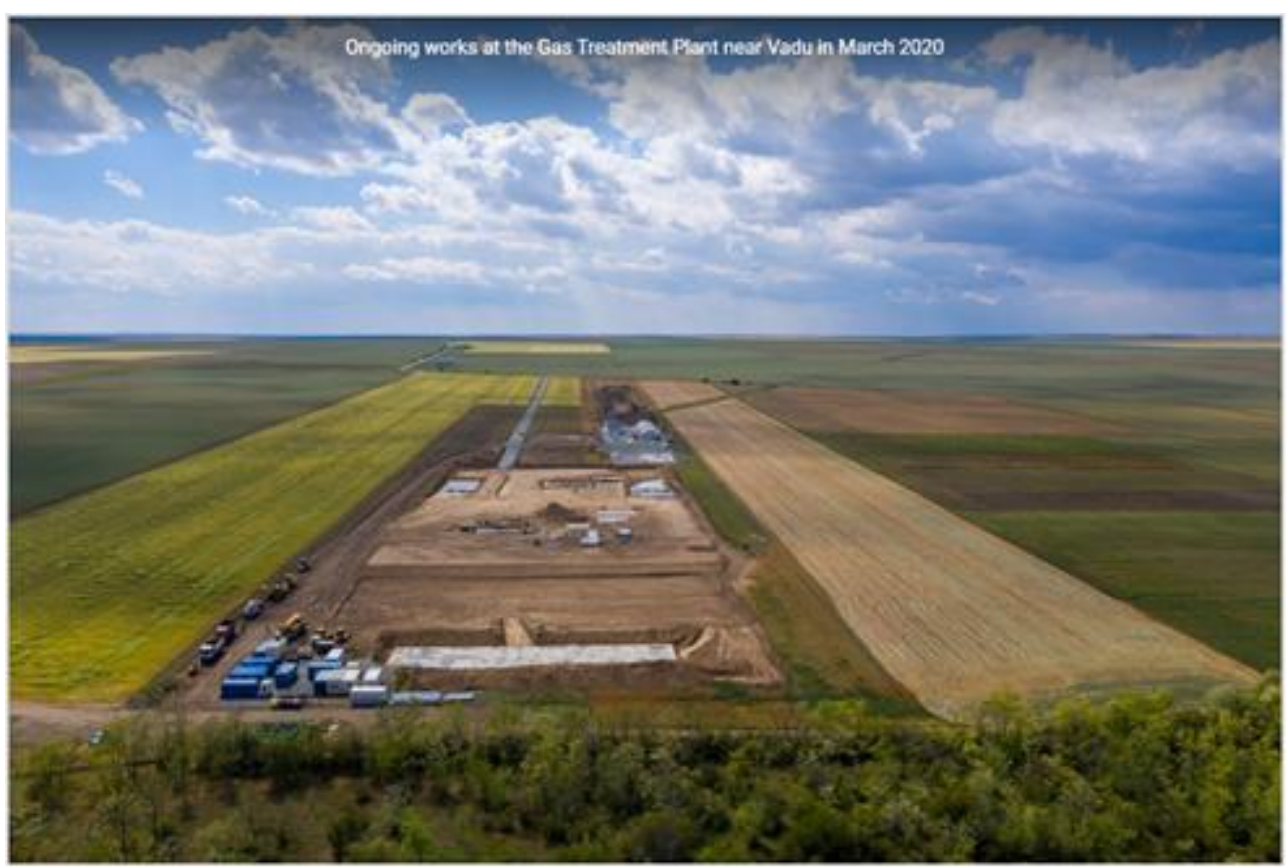

Fig. 14.4. Ongoing Works at Gas Treatment Plant in Vadu Site [2] 


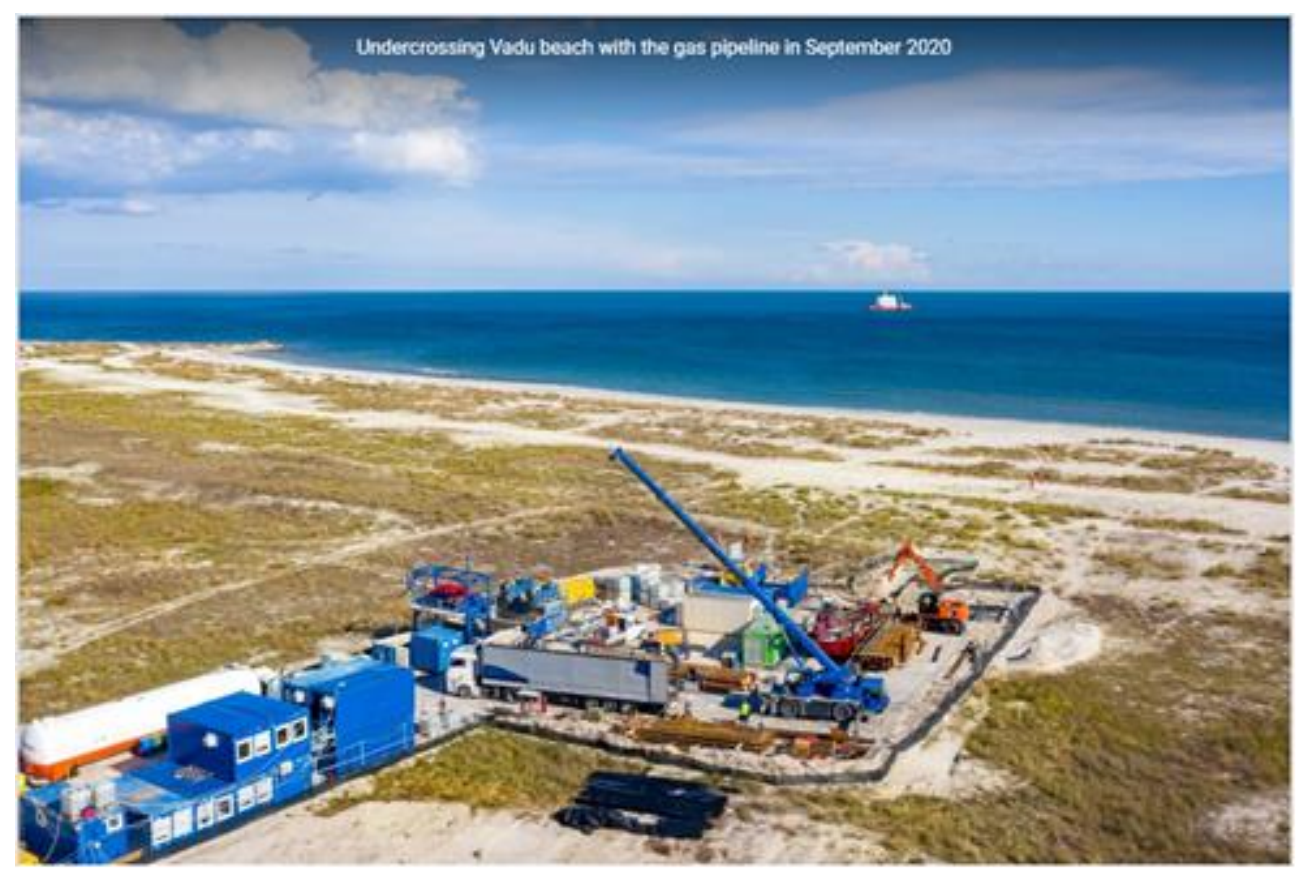

Fig. 15.1. Undercrossing Vadu Beach with the Gas Pipeline [2]

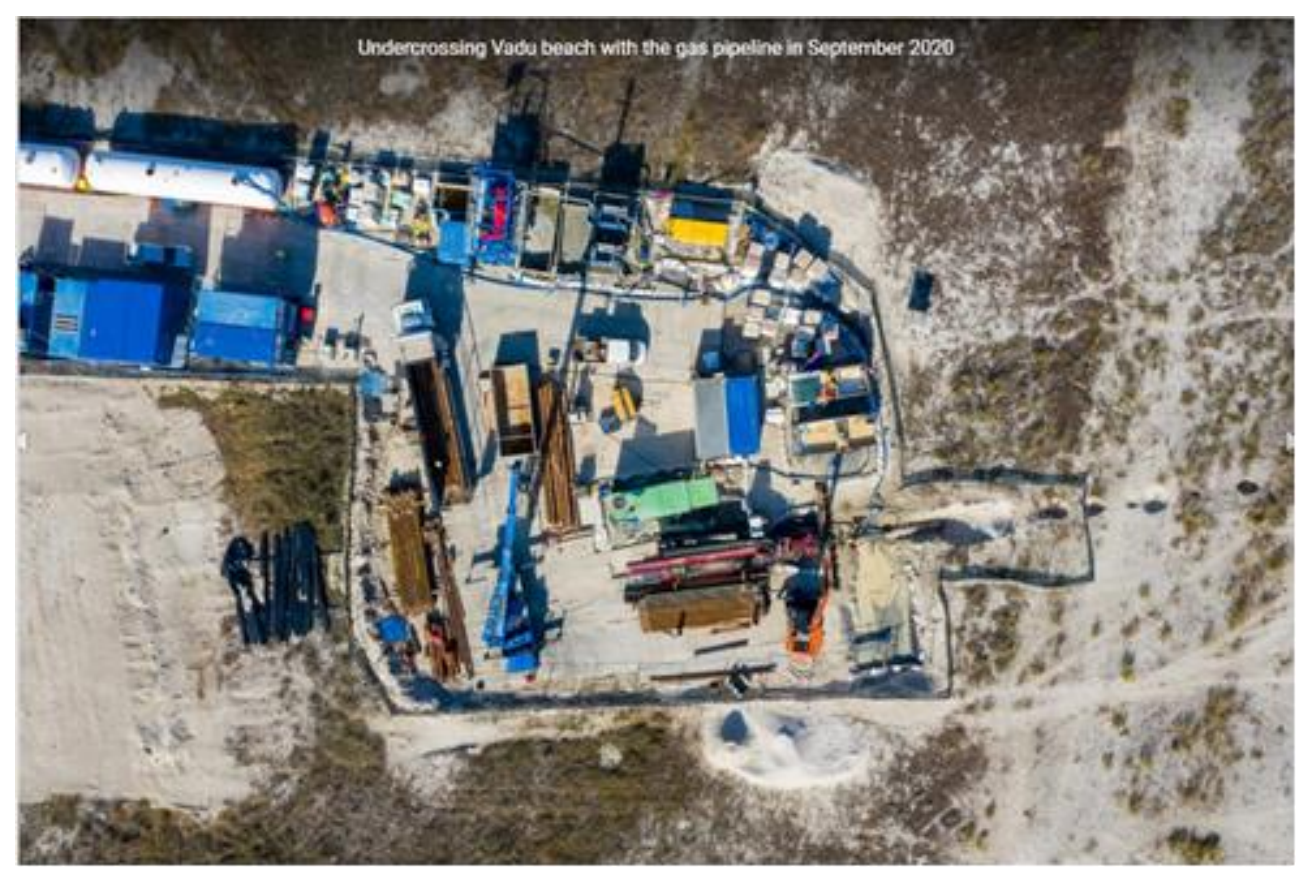

Fig. 15.2. Undercrossing Vadu Beach with the Gas Pipeline [2] 


\section{Sciendo $_{190}$ Ovidius University Annals Series: Civil Engineering, Year 23, 2021}

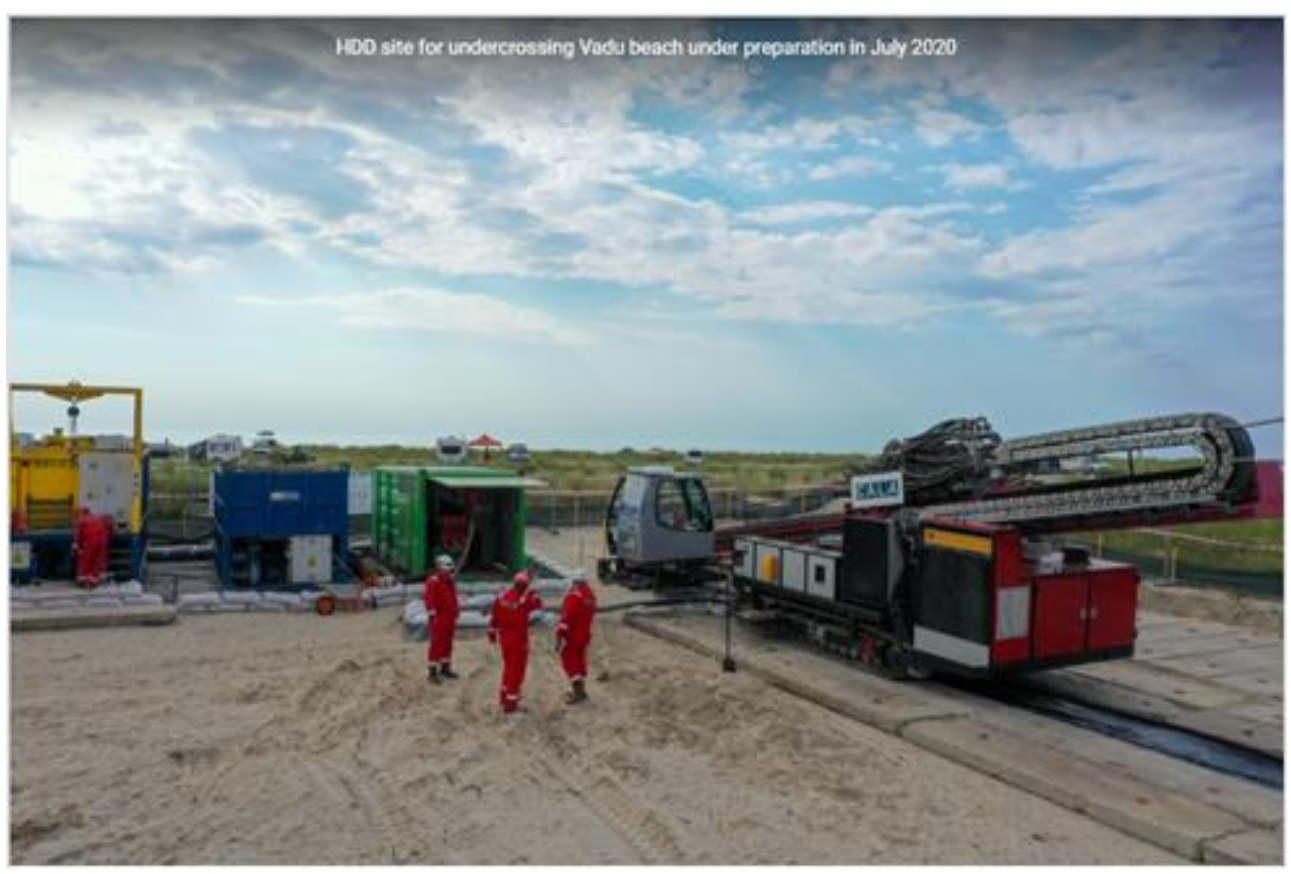

Fig. 16.1. HDD Site for Undercrossing Vadu Beach under Preparation [2]

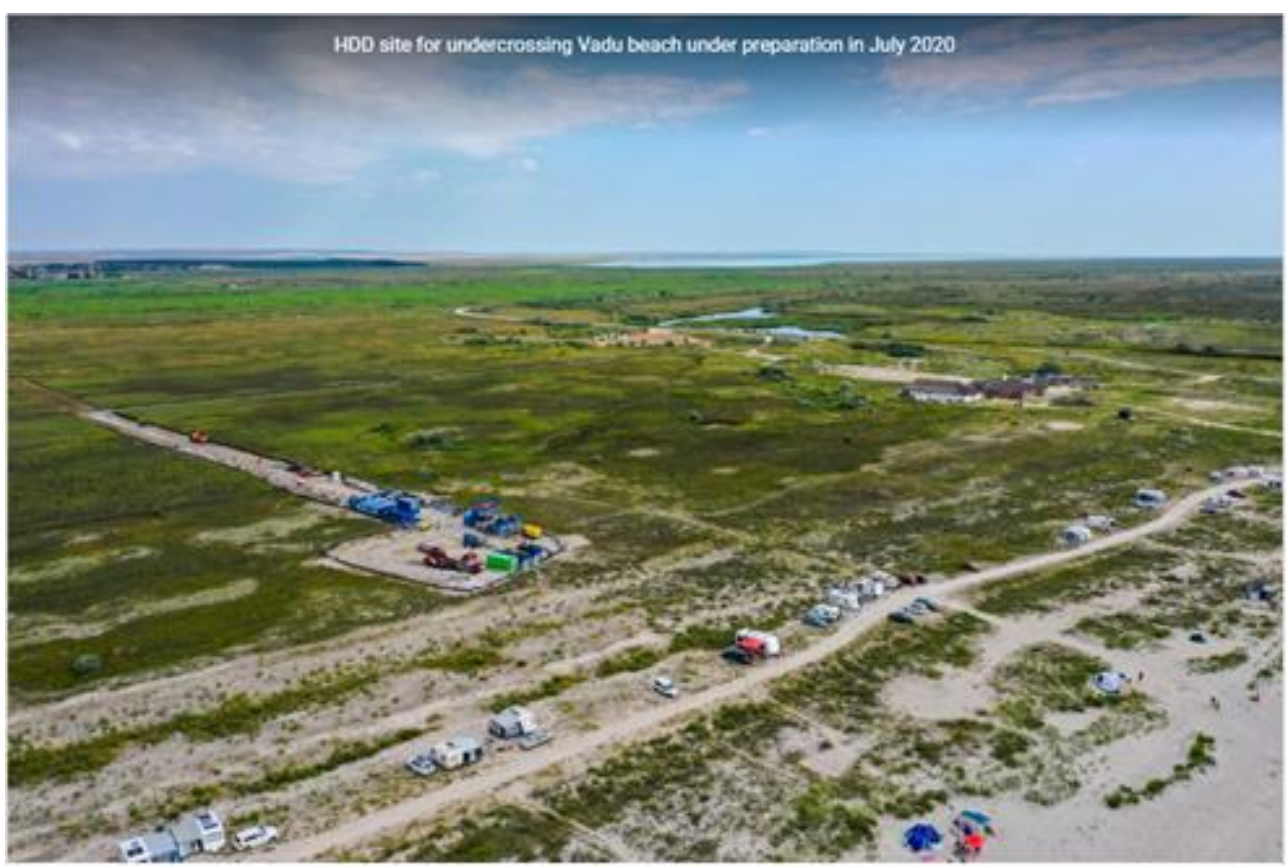

Fig. 16.2. HDD Site for Undercrossing Vadu Beach under Preparation [2] 


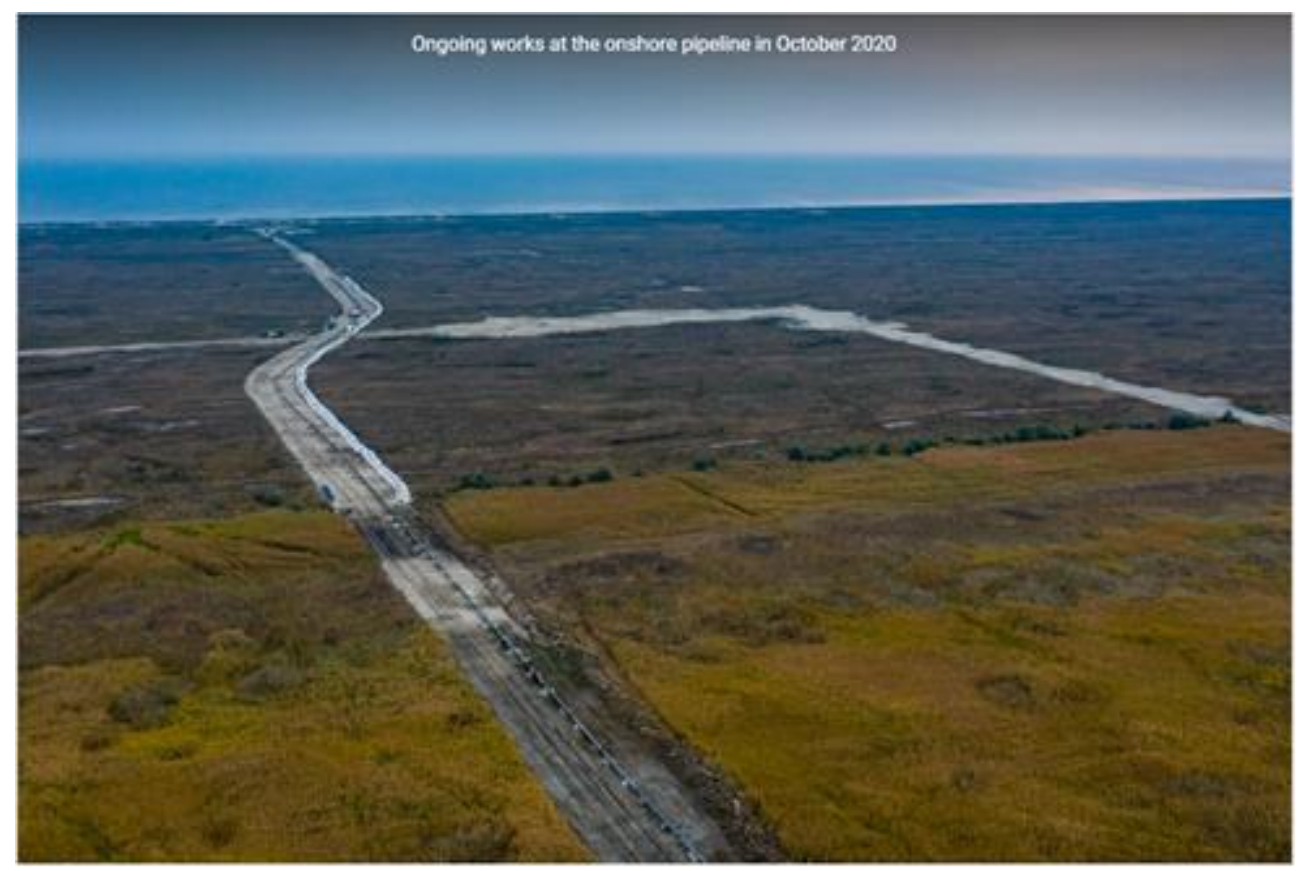

Fig. 17. Ongoing Works at the Onshore Pipeline [2]

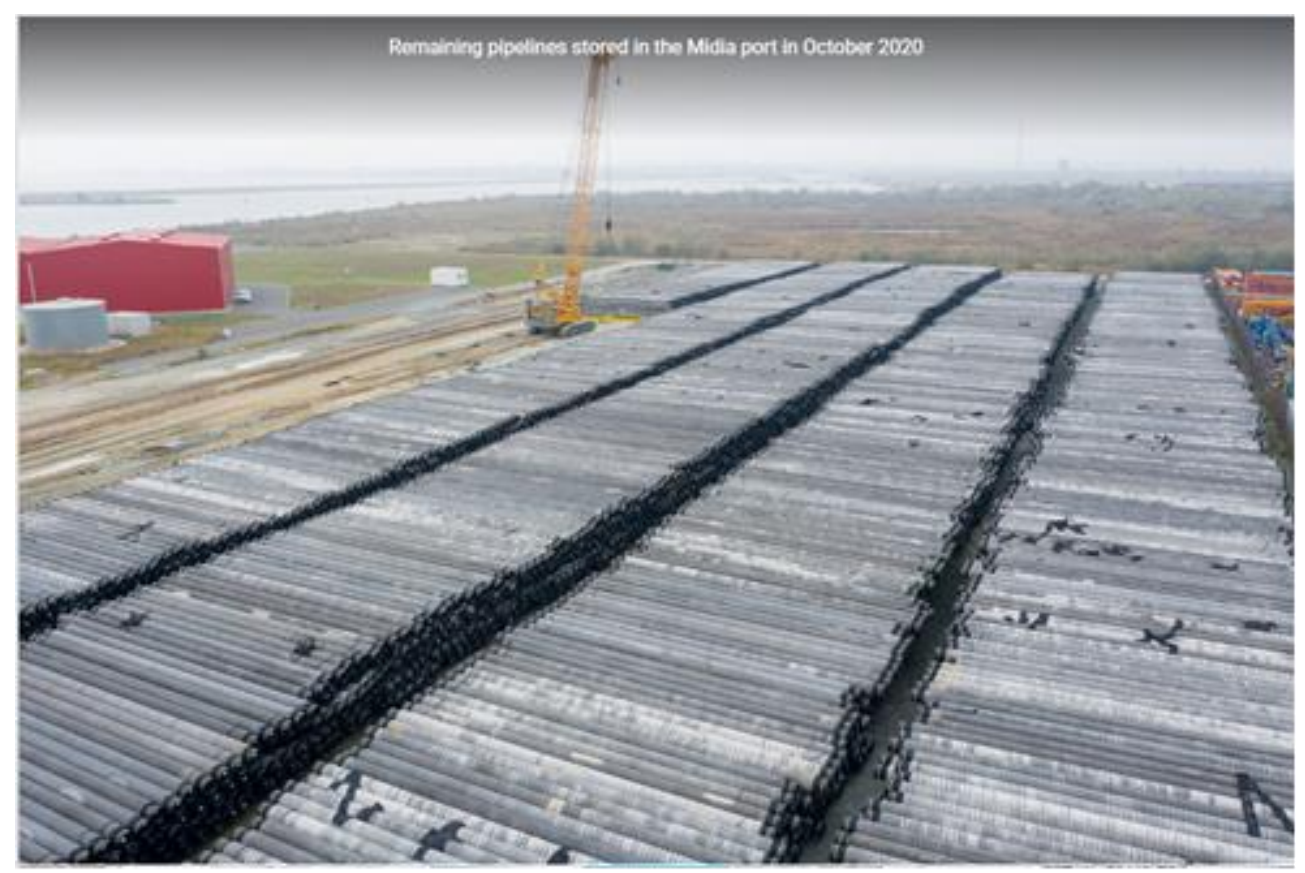

Fig. 18.1. Remaining Pipelines Stored in the Midia Port [2] 


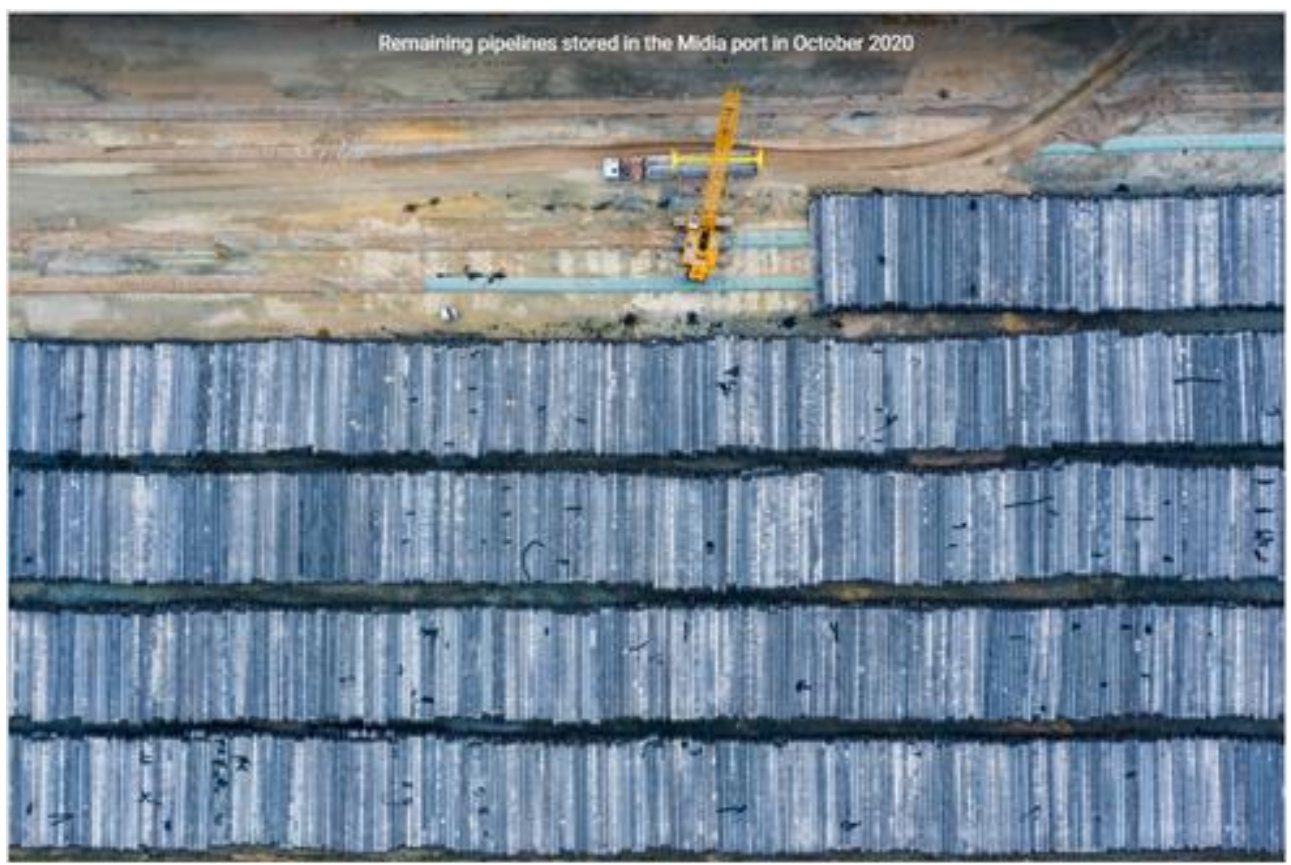

Fig. 18.2. Remaining Pipelines Stored in the Midia Port [2]

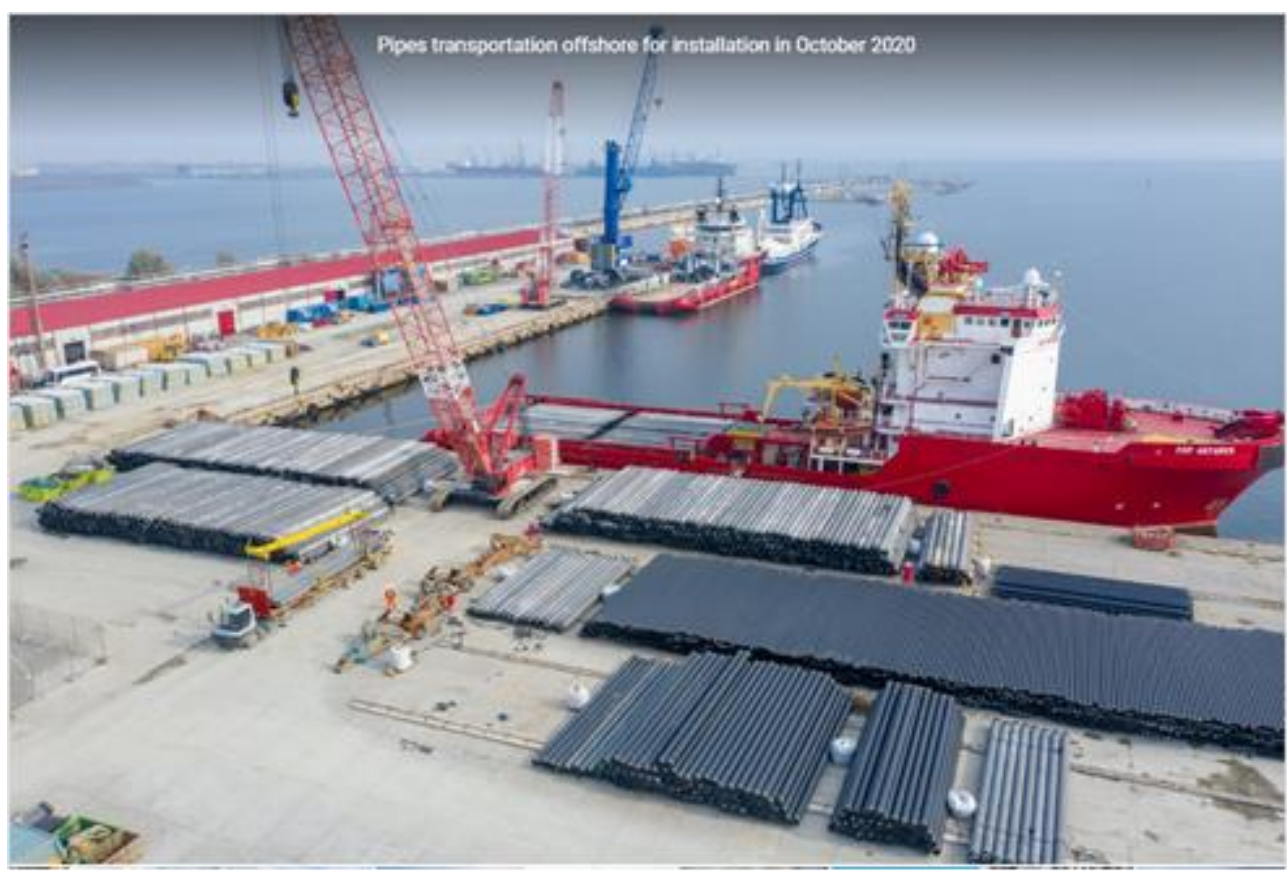

Fig. 19.1. Pipes Transportation Offshore for Installation [2] 


\section{sciendo}

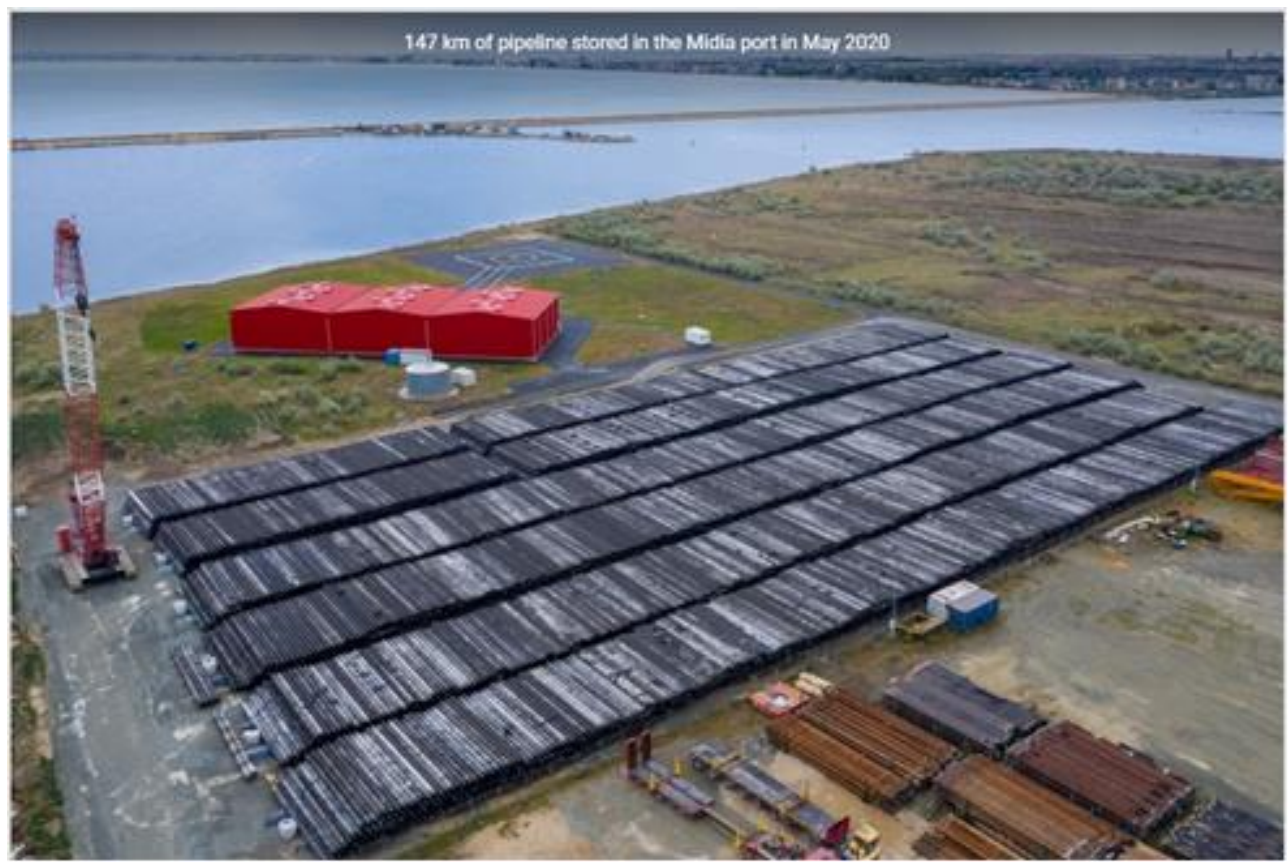

Fig. 19.2. $147 \mathrm{Km}$ of Pipeline Stored in the Midia Port [2]

\section{REFERENCES}

The following referenced documents are indispensable for the application of this document. For dated references, only the edition cited applies. For undated references, the latest edition of the referenced document (including any amendments) applies.

[1] Black Sea Oil \& Gas Company, Company Site [Online], available at Midia Gas Development - Black Sea Oil \& Gas : Black Sea Oil \& Gas (blackseaog.com)

[2] Black Sea Oil \& Gas Company, Company Site [Online], available at Media gallery Black Sea Oil \& Gas : Black Sea Oil \& Gas (blackseaog.com) 21.12.2021

[3] Black Sea Oil \& Gas Company, Company Site [Online], available at Quality - Black Sea Oil \& Gas : Black Sea Oil \& Gas (blackseaog.com)

[4] ISO 10005 / 2018 - Quality management systems - Guidelines for quality plans

[5] BSOG-QA-SPC-001-D01 / 2018 - Quality Requirements for Contractors

[6] ISO 9000:2015 - Quality management systems - Fundamentals and vocabulary

\section{Note:}

Roxana Doina Schiaua - Project data operator at Black Sea Oil \& Gas SA, Lumina, Constanta, Romania (corresponding author to provide phone: +407-379-02085; e-mail: schroxa@yahoo.com.) 